نقد و بررسى نقش رسالتباورى در تعيّن هنرى و ناكامى تقليد ادبى با تأكيد بر غزليات

حافظ*

\title{
Ahmet Yeşil**
}

Hojjat Abbasi***

جكيده

هنر فرايند عملكرد متمايز و برجسته است. اين تفاوت و تشخص موجب استقبال مخاطبان

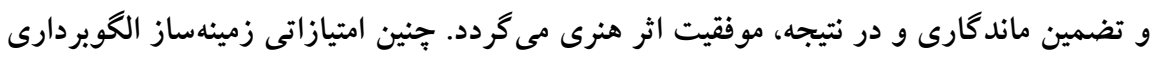

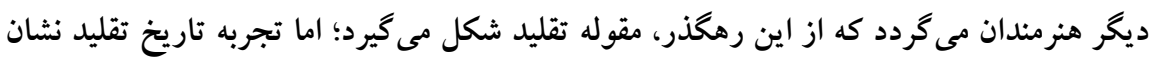

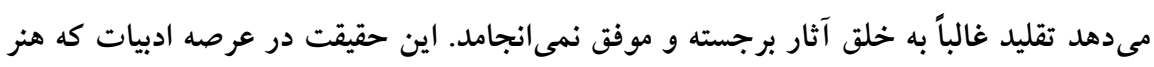

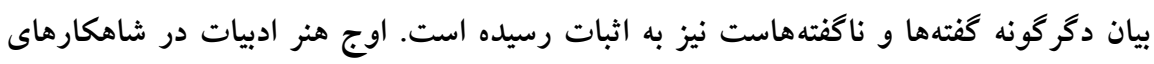

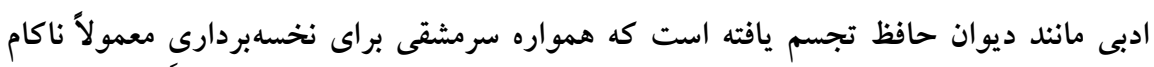
ديكر اديبان بوده است.

يُزوهش حاضر در عين توجه به سابقه همه تحقيقاتى كه مستقيم و غيرمستقيم رموز برترى

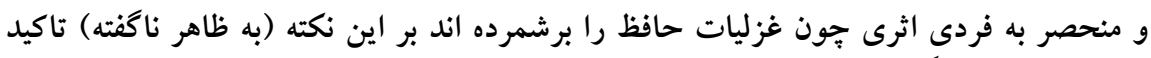

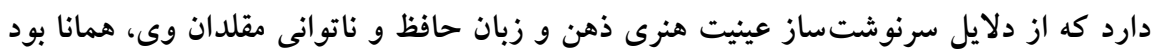

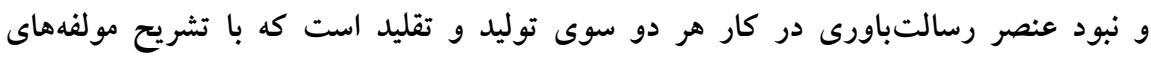

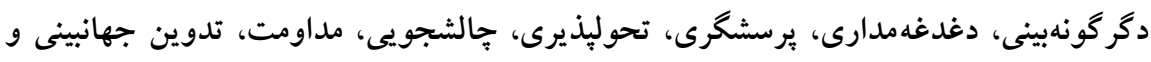
فرهنگسازى با روش توصيفى-تحليلى تبيين مى گردد. كليدوازَّان: حافظ، رسالتمدارى، تعيّن هنرى، تقليد ادبى

\footnotetext{
* Araştırma makalesi/Research article. Doi: 10.32330/nusha.959991

** Dr. Öğr. Üyesi, Sakarya Üniversitesi, İlahiyat Fakültesi, Türk İslam Edebiyatı Anabilim Dalı. Sakarya University, Faculty of Theology, Department of TurkishIslamic Literature. Sakarya-Türkiye e-posta: ahmetyesil@sakarya.edu.tr Orcid No: https://orcid.org/0000-0002-0606-5177.

${ }^{* * *}$ Dr. Öğr. Üyesi, Payame Noor Üniversitesi, Edebiyat ve Yabancı Diller Fakültesi, Fars Dili ve Edebiyatı Bölümü Öğretim Üyesi. Payame Noor University, Faculty of Literature and Foreign Languages, Department of Persian Language and Literature. eposta: hoojan3@yahoo.com Orcid No: 0000-0003-1095-0379

Makale Gönderim Tarihi: 30.06 .2021
}

Makale Kabul Tarihi $\quad$ : 22.11.2021

NÜSHA, 2021; (53): 361-386 


\section{Misyon İnancının Sanatsal Nesnellik ve Edebi Öykünme Başarısızlığındaki Rolünün Hâfız Gazelleri Üzerinden Analiz ve Değerlendirilmesi \\ $\ddot{O} \mathbf{z}$}

Sanat, ayırt edici ve olağanüstü bir performans sürecidir. Sanatın bu imtiyaz ve üstünlüğü; muhataplar tarafından beğenilmesine, kalıcı olmasına ve sonuç olarak sanat eserinin başarılı olmasına olanak sağlar. Bu tür ayrıcalıklar aynı zamanda, taklit türünün oluşmasına zemin hazırlayan diğer sanatçıların taklit etmelerinin de önünü açar. Ancak, taklit tarihinin deneyimi, taklidin çoğu zaman olağanüstü ve başarılı sanat eserlerinin yaratılmasına yol açmadığını göstermektedir. Bu hakikat, söyleneni ve söylenmeyenleri farklı ifade edilme sanatı olan edebiyat alanında da kanıtlanmıştır. Hâfız'ın Divanı gibi edebiyatın zirvesi olarak kabul edilen edebi şaheserler, yazarların öykündüğü kigenellikle bu yolda başarısız oldukları- eserler olmuştur.

$\mathrm{Bu}$ çalışma, Hâfız Gazelleri gibi bir eserin üstünlük ve eşsizliğinin sırlarını doğrudan ve dolaylı olarak sıralayan tüm araştırmaların tarihini ele alırken, aynı zamanda Hâfız'ın (görünüşte dile getirilmeyen) dil ve zihninin sanatsal nesnelliğini ve taklitçilerinin yetersiz kalmalarının önemli nedenlerini vurgulanmaktadır. Ayrıca çalışmada, hem sanat eserinin var edilişinde hem de taklit çalışmalarında misyon-inanç unsurunun varlığı/yokluğu; endişe, sorgulama, değişebilirlik, meydan okuma, azim, dünya görüşü ve kültür oluşturma gibi bileşenler tanımlanarak betimsel-analitik yöntemle açıklanmaya çalışılmıştır.

Anahtar kelimeler: Hâfız, Misyon İnancı, Sanatsal Objektiflik, Edebi Öykünme

Critique and Analysis of the Role of Belief in Mission in the Artistic Objectivity and Failure of Literary Imitation with an Emphasis on Ḥāfeẓ's Ghazals

\section{Abstract}

Art is a distinctive and outstanding performance process. This difference and prominence make the audience welcome and ensure its durability and consequently, the success of the work of art. Such privileges pave the way for the imitation of other artists, through which the category of imitation is formed. However, the experience of the history of imitation shows that imitation often does not lead to the creation of outstanding and successful works. This fact has also been proven in the field of literature, which is the art of expressing what is said and what is not said. The pinnacle of literary art is embodied in literary masterpieces such as Hāfeẓ's Divan, which has always been a model for the often failed copying of other belletrists.

The present study pays attention to the history of all researches that directly and indirectly enumerate the secrets of superiority and uniqueness of a work such as Hâfez's lyric poems and also emphasizes that (seemingly unspoken) one of the crucial reasons for the artistic objectivity of mind and language of Hăfez and the inability of his imitators was the existence and the absence of mission-belief element in the work of both production and imitation, which is explained by the descriptive-analytical method through describing the components of heterogeneity, concern, questioning, variability, challenge-seeking, persistence, worldview development and culture-building. 
Keywords: Hāâfez, Missionary orientation, Artistic Objectivity, Literary Imitation

\section{Structured Abstract}

Art is a distinctive and outstanding performance process. The most obvious manifestation of this prominence in the field of literature are literary masterpieces which, while stimulating their audiences to create similar works, block the way for the multiplicity of masterpieces. Because these works both gain the nature and taste of their sympathizers and practically narrow the field of creation to create a superior and better or at least equiponderant work. Contrary to this fact, the category of literary imitation, that is, conscious and unconscious copying of a prominent work always happens. But as art history shows, imitation often does not lead to successful works.

Hafez's Divan Ghazaliyat is one of these literary masterpieces that has always been imitated. However as expected, it has never resulted in the emergence of a work worthy of the title of literary masterpiece. As a result of previous research, there is an important question. Why does imitation not usually lead to the creation of outstanding works, despite having successful models such as Hafez's Divan? It can be said that the lack of imitation works has been met with memorization techniques and attributes such as ambiguity, mythology, and literary innovation. However, the present study concludes with an analytical-descriptive approach that in addition to the above, one of the most important reasons for the failure of imitation of Hafez's style and context is the deprivation of his imitators of two crucial elements of questioning and believing in the mission. Who is human and where and why he came from is one of the oldest and most frequent and at the same time most unanswered questions of human life and has been raised many times in Hafez's poems. These questions seem to have been answered by Hafez by discovering the fact that the purpose of human creation was the mutual lovemaking of the creator and the created. This discovery leads Khajeh Hafez on a mission of intellectual and cultural enlightenment in order to disrupt the intellectual, emotional and habitual system in the world around him in accordance with his new discovery and to throw out a so-called new plan. These insights and the resulting motivations bring four important intellectual and literary achievements to Hafez's poetry that imitation works are deprived of.

First, the esoteric belief in a transpersonal and humanitarian mission and action towards it confronts the poet with great challenges such as a relentless debate with religious hypocrites, political leaders and the foolish masses who, as historical testimony, prove the authenticity of his beliefs and actions, and convince the audience more than before that what the poet claims and propagates is based on a true belief and so it is not merely an ostentatious or poetic gesture felt through works based on imitation.

Second, the challenging image of life and its ambiguities and conflicts, portrayed through missionary actions and sayings, paves the way for the acceptance of Hafiz's widely used theory of welcoming the incompatible habit. Because, the course of the mission-oriented and ups and downs of the poet's life and its reflection in his poems, could be strong evidence of the fact that, contrary to popular belief, this is risking and 
acceptance of adversity that lead to the blossoming and fulfillment of hopes and aspirations, not an escape from them.

Third, the effects of intellectual-psychological confrontation of the poet's with internal challenges such as exploring the cause of his creation and existence and external challenges such as conflicts with ascetics and Sufis and hypocritical and antiscience people, gives the poet's groans, imagination, and poetic images a double depth and fascination. Because the poet speaks of feelings and pain that she has personally experienced, not to depict spaces and situations that are only the result of the exaggerated speech.

Fourth, because of these questions, missions, and challenges, a new literary style emerges that has not been common in the standard lyric style before. Hafez's different style of lyric poetry, known as the disturbed order, is in fact the result of his practical attention to a variety of individual and collective issues from lovemaking, embarrassment, perplexity, pessimism, and apostasy to confronting a skeptical Sufi and an extremist guard and a credulous king. This is while the imitators and followers of Hafez or like their predecessors, according to the traditional style of lyricism in their poems have spoken only about love's groans and separation or if, like Hafez, they have turned to various contents and issues, the lack of a spirit of belief in mission in their lives and literature have prevented the formation of the principle of the "originality of belief" in their work.

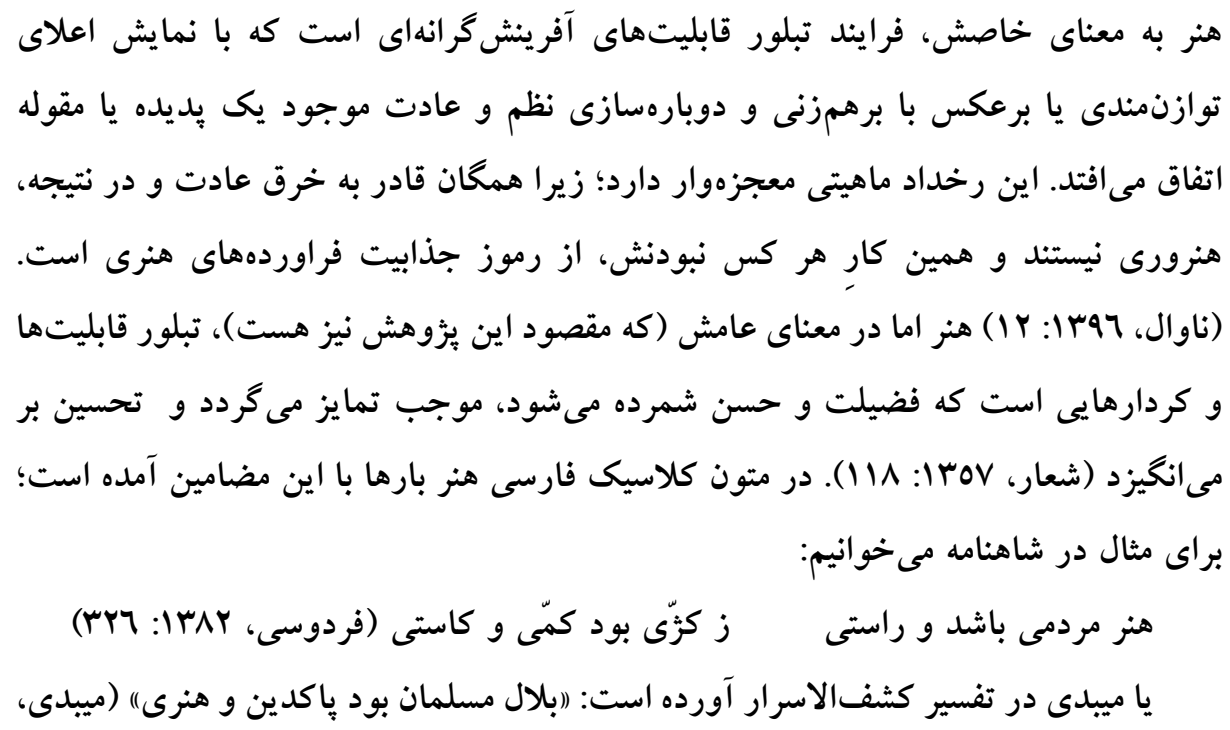




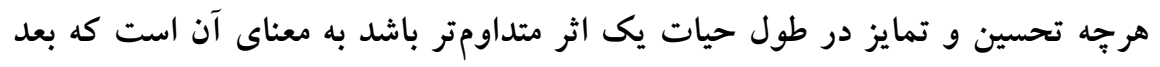

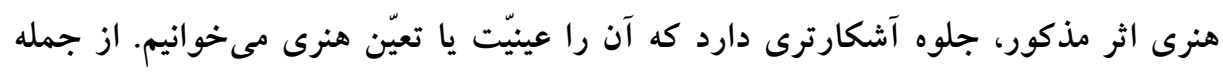

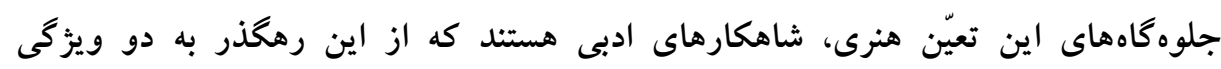

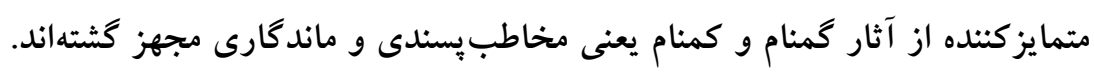
از آنجا كه شاهكارهاى ادبى نمونههاى اعلاى عينيت هنرى يك زبان و فرهنى هستند و

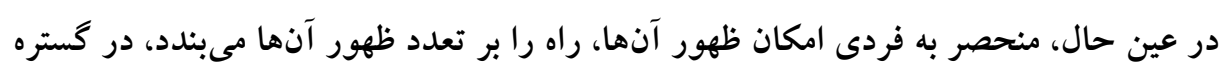

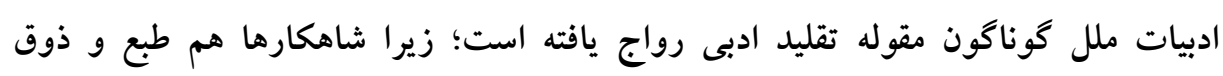

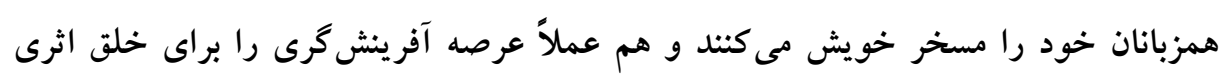

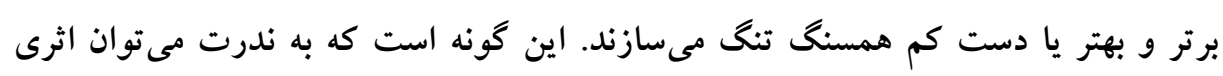

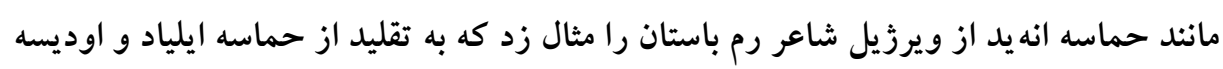

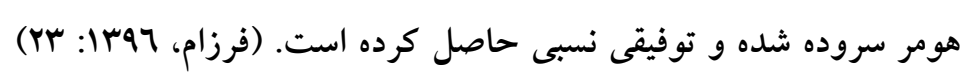

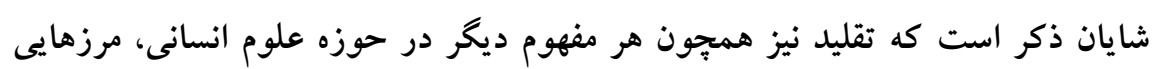

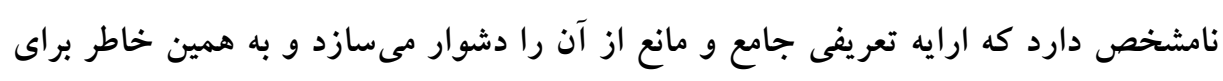

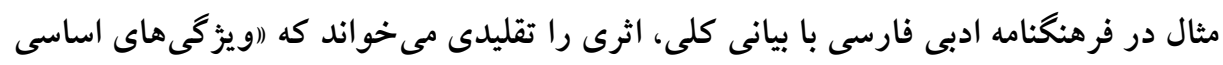

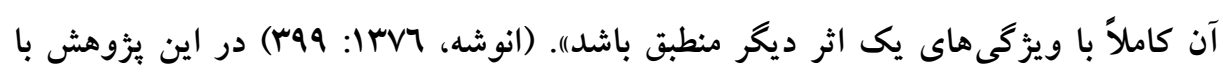

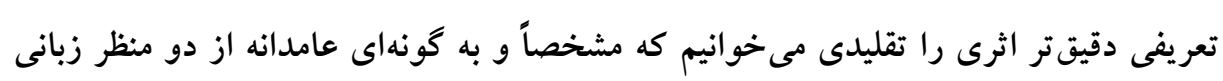

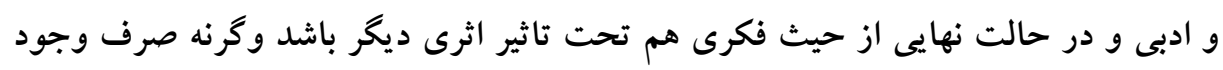

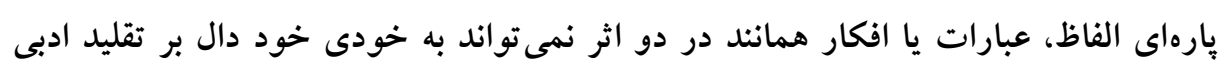

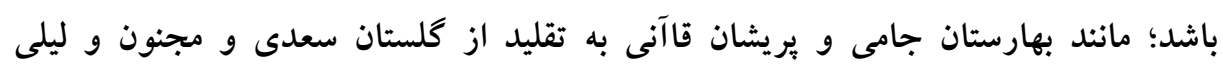
اميرخسرو دهلوى به تقليد از ليلى و مجنون نظامى. بانس. در قلمرو زبان و ادب فارسى بارزترين نمونه نمود واقعيت ناهمكونى توليد و تقليد،

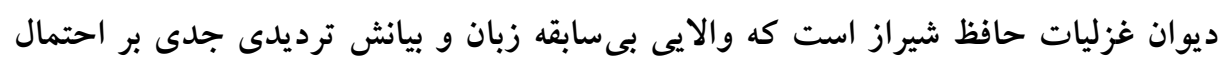

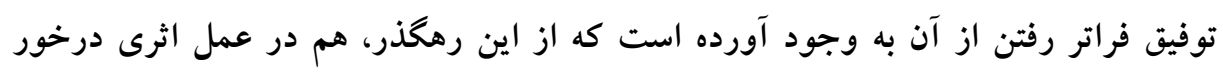


رقابت و مقايسه ظهور نكرده و هم جارهاى جز تداوم حيات غزلسرايى فارسى زير سايه روش

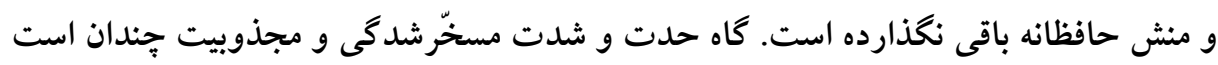

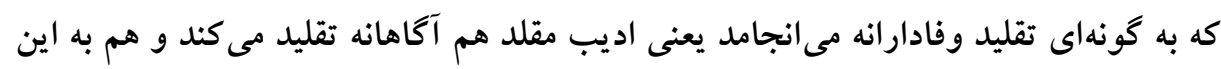

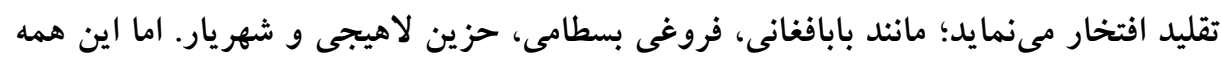

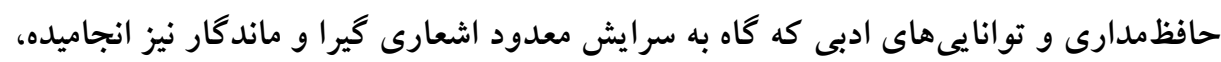

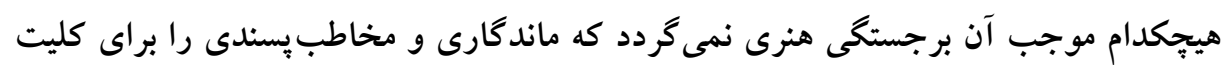

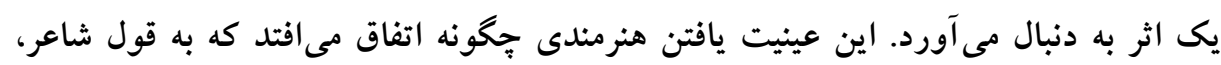

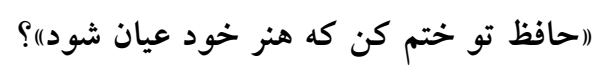

با توجه و استناد به آن همه تحقيقات روشنكر حافظيزوهى مى توان به آسانى علت امر را به ناتوانى مقلدان در شخصيت بردازىها، اسطورهسازىها، ايهام و ابهام آفرينىها،

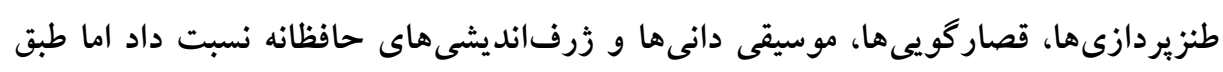

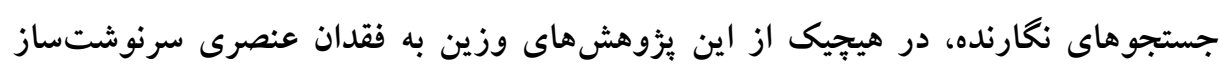

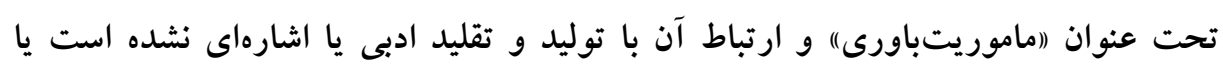

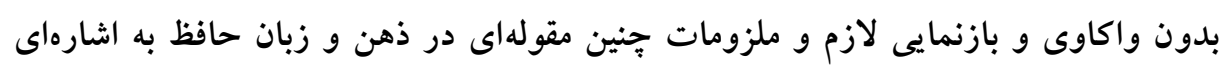

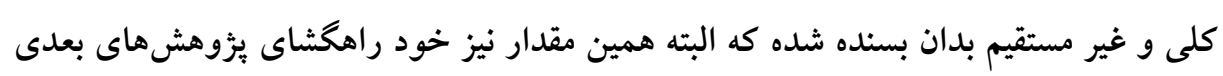
از اين دست است.

اكنون اين كه جه زمينها و مولفه هايى در شعر حافظ نمود ماموريتباورى است و جگگنه حضور يا غياب آن، موجب عينيت هنرى و تضمين جاودانكى مخاطبمدار در متون خلاق و و ودينو

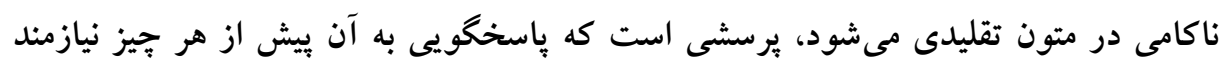

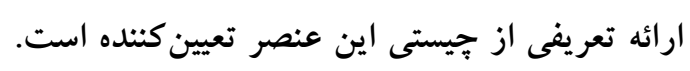

$$
\text { رسالتباورى }
$$

از جمله شاخصههاى فكرى-عاطفى آدمى، احساس مسئوليت در قبال همنوع و سرزمين

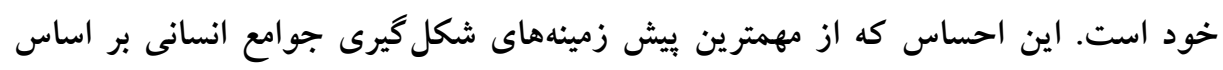

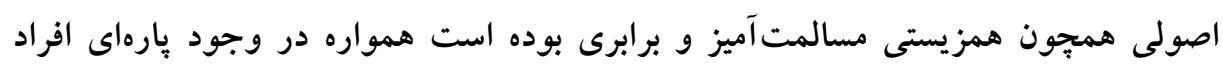


تبلورى بيشتر داشته و سبب ظهور بشردوستانى تحت عنوان ييامبران، يُشوايان و مصلحان

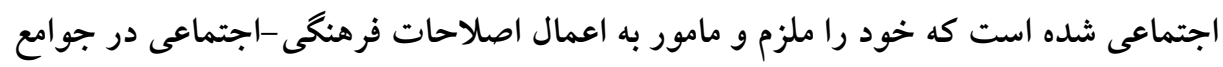

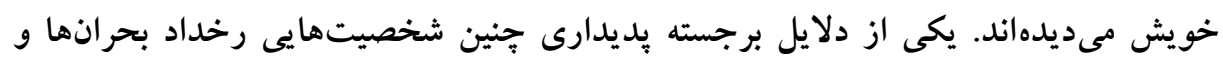

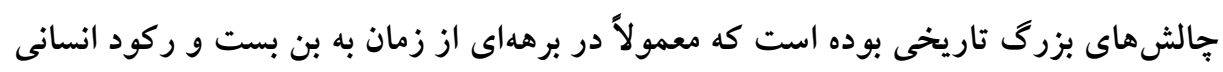

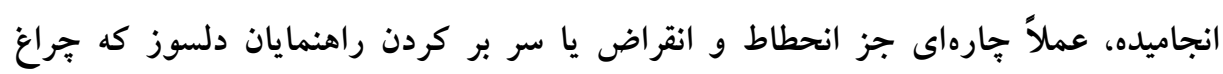
روشنگرى فرا راه بشر بخيرند باقى نمى گذارد.

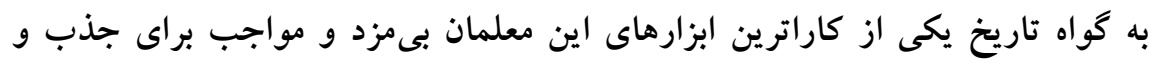

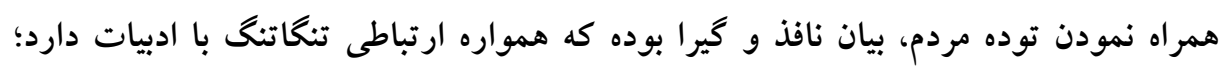

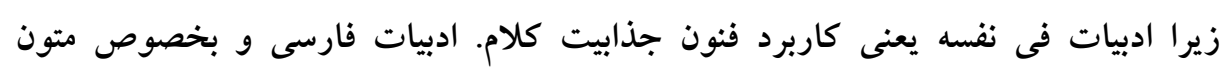

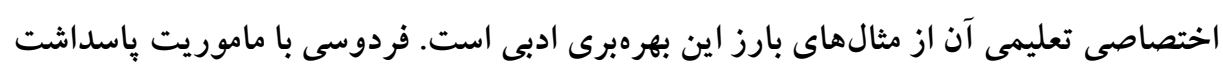

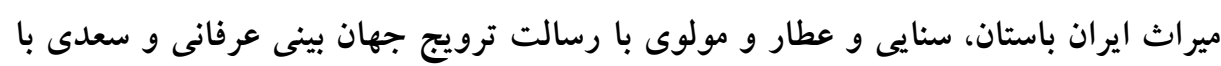

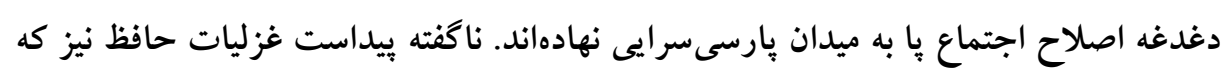

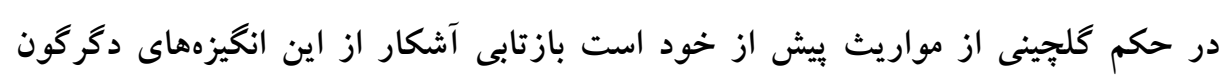

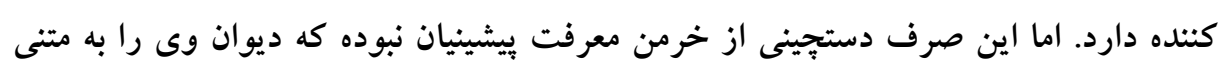
اصلاحطلب و تحول كرا تبديل كرده است.

هم شرايط خاص تاريخى عصر خواجه و هم بينش و منش شخصى وى در اين مهم

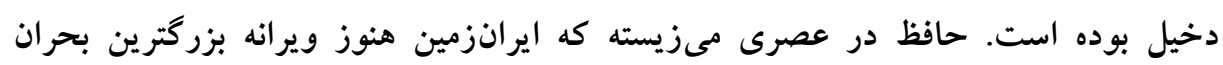

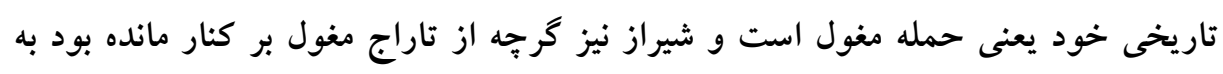

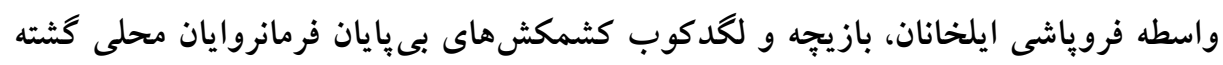

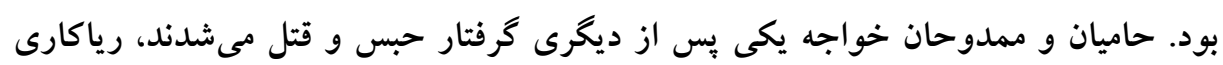

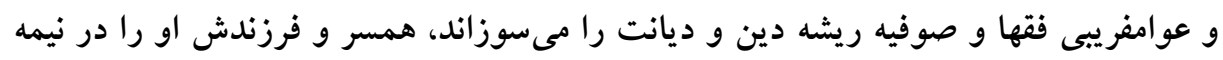

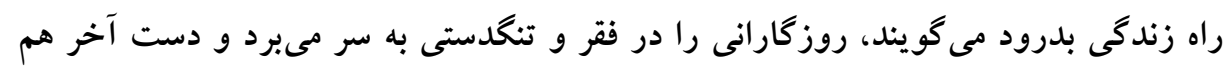

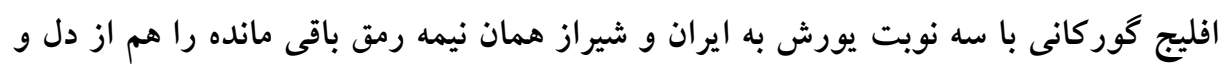


جان مردم و ميهن مىستاند و حال و هواى قرون وسطايى بيشاييش بر كشور مستولى مى

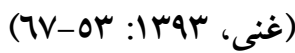

در جنين شرايطى حافظ آكاهانه يا ناخودآَاه با سه رسالت كلان فردى و جمعى با به عرصه روشنگرى مى نهد. ماموريت فردى وى كه در حقيقت نخستين دغدغه و الزام بايسته هر جان انديشمند است كثف راز وجود است تا بداند كه كيست و جيست و و از كجا آمده و و به وريه كجا مىرود. آن قدر اين دغدغه در طول حيات خواجه بررنح بوده كه هم ابياتى فراوان در اشاره به ناممكنى جنين اكتشافى از خود بر جاى نهاده است؛ نظير: سخن از مطرب و مى كو و راز دهر كمتر جو كه كس نخشود و نخشايد به حكمت اين معما را (همان: (11) هم بويزه در اشعارى كه صبغه عرفانى دارند جنين مىنمايد كه مأموريت نخست خود را

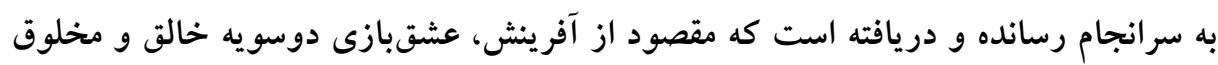

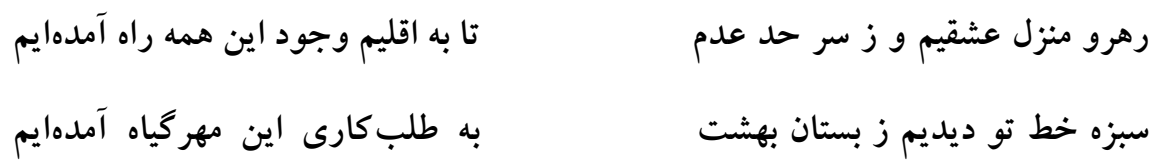
(همان: (1AY)

بـ ماموريت نخست آدمى، تعامل درست است با عشق كه در واقع امانت الهى است:

بى دلى سهل بود گر نبود بى دينى كر امانت به سلامت ببرم باكى نيست (همان: (هr)

ماموريت دوم روشنكرى فكرى-فرهنكى بوده كه در كسوت سفارشهاى اخلاقى و

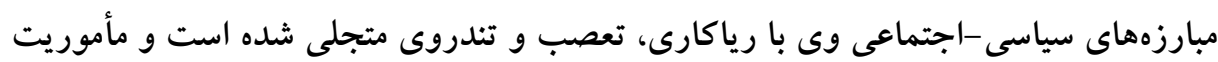

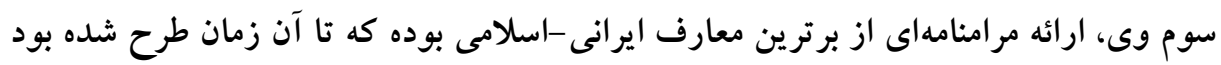

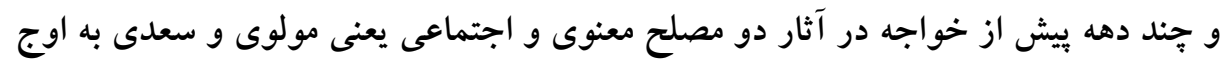


خود رسيده اما جكيدهسازى نشده بود. اين انخيزه در تركيب با حسن خداداد بيان سحر انكيز،

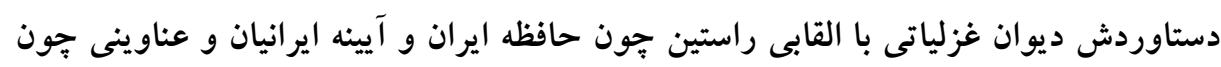
لسان الغيب و خواجه راز براى شاعر مىشود. همجِون همه دستاوردهاى كلان بشرى، اين توفيق جشمخير هم به سرعت الكويى براى

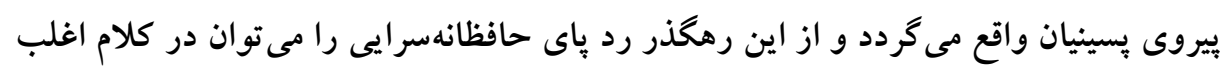

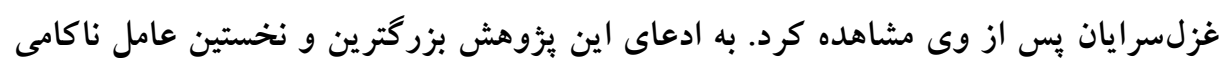

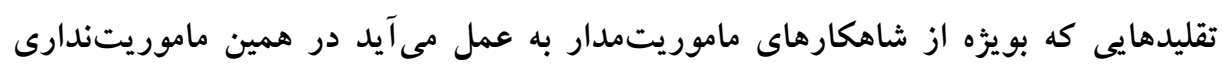

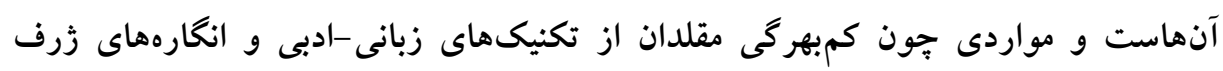

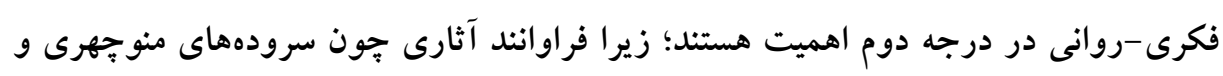

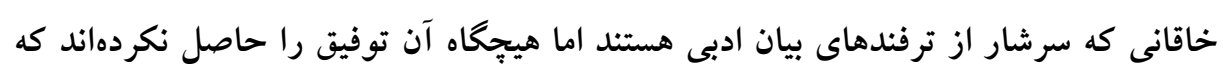

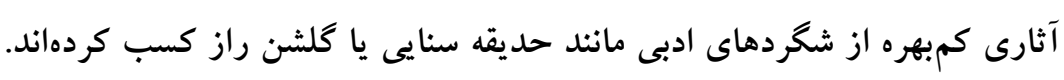
اين كه جرا و جّكونه بود و نبود اصل رسالتمندى تا اين حد در توفيق يا ناكامى يك

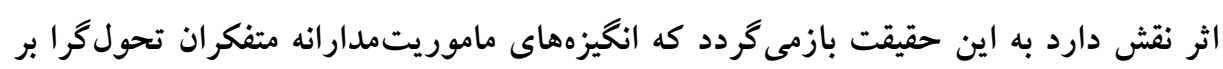

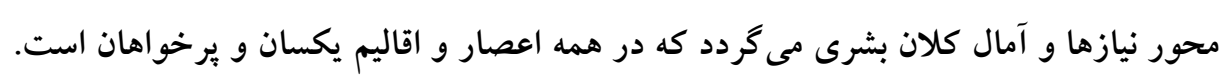

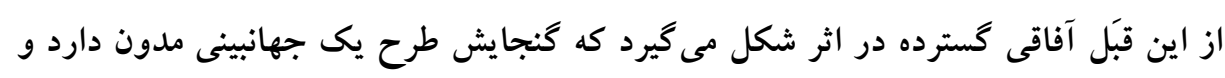

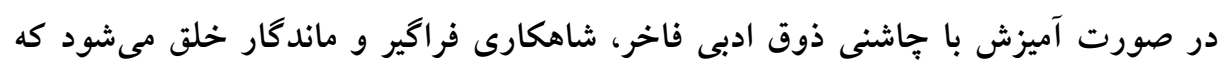

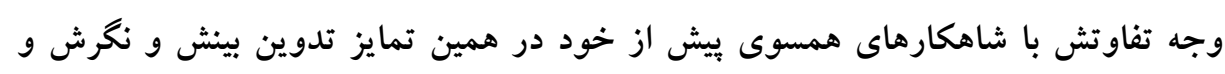

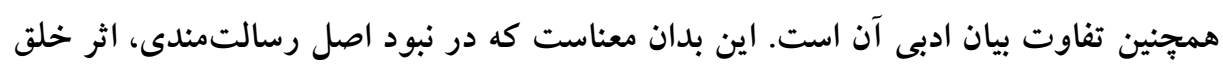

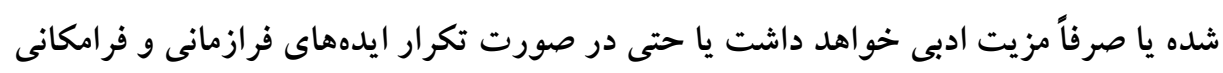

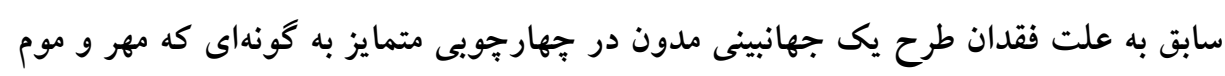

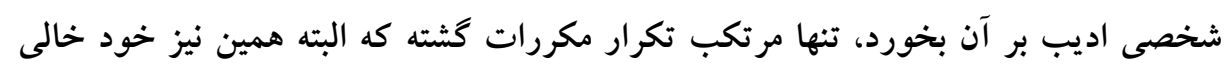
از لطف نيست. برسش گرى و دغدغهمدارى 
اكر انسانيت مرتبهاى ميان حيوانيت و فرشتخى است، آنجه وى را ناخودآكاه متمايل به

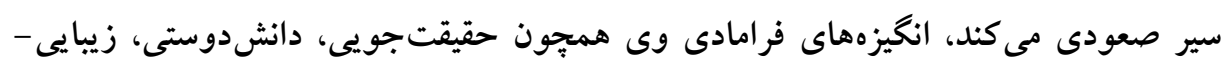

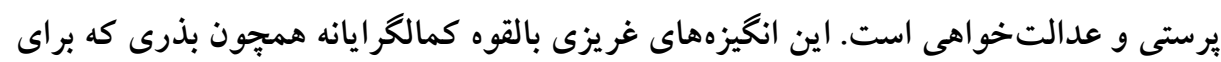

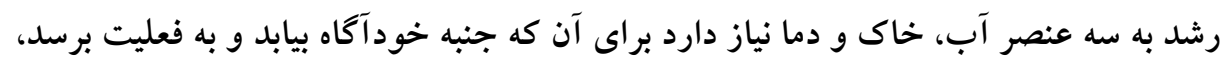

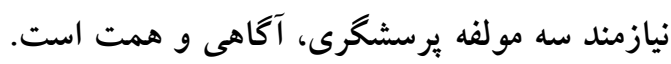

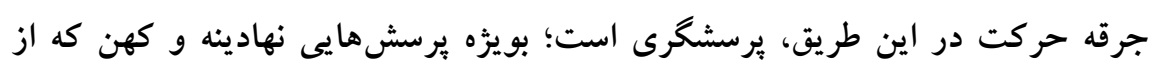

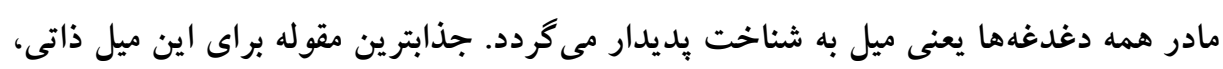

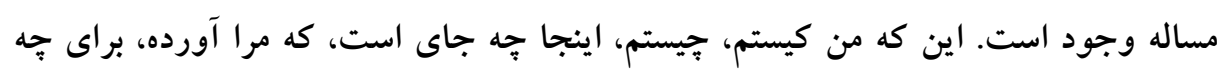

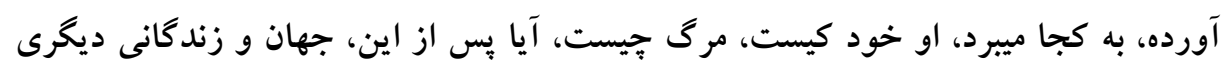

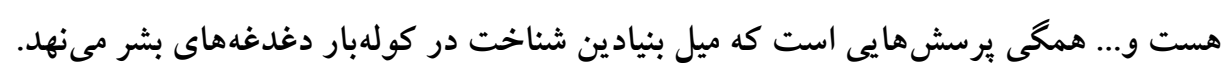

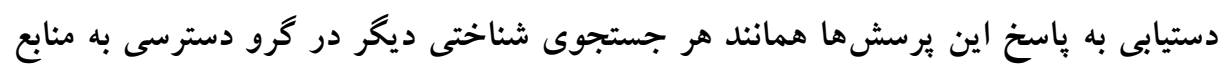

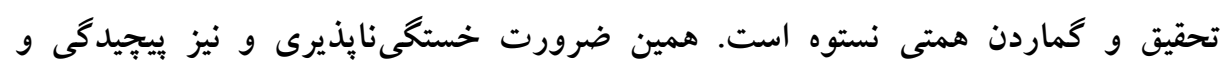

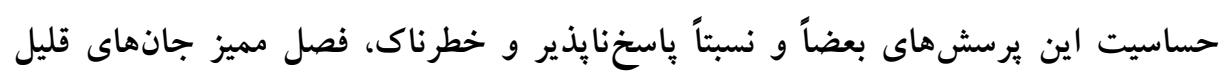

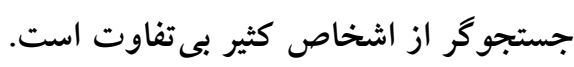
حافظ يكى از اين جانهاى برسشخر است:

آواز سوال حيرت آمد (همان: lor)

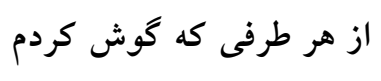

از اين رو ديوان اشعارش مجمع برسشها و دغدغههاى فردى و جمعى است. وى مدام

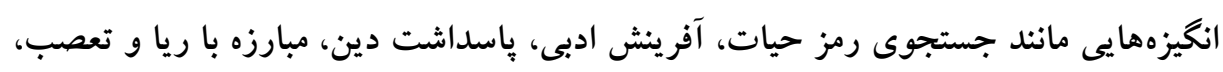

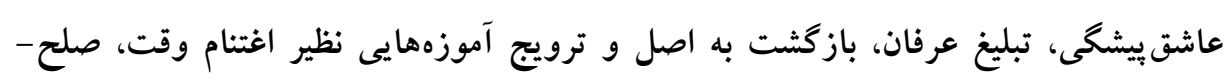

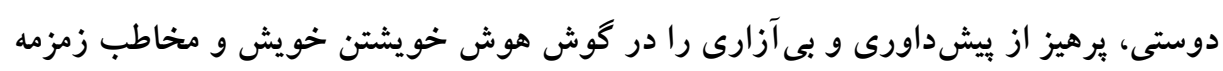

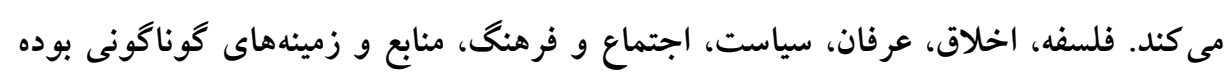

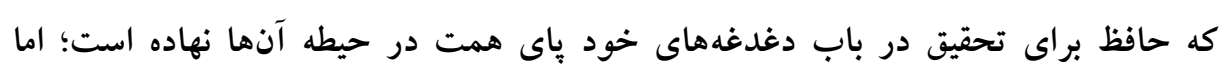

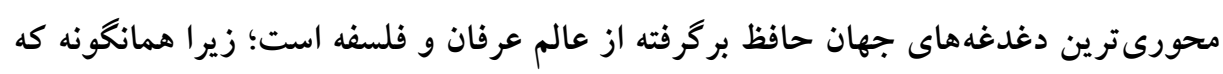
بيان شد، بزر كترين سوال و ابهام جانهاى برسشخر همانا معماى وجود داس است و فلسفه و و عرفان، منابع جواب كويى به يرسشهايى از اين دست هستند. براى نمونه: 
لزوم بازگثت به مبدأ:

كه اى بلندنظر شاهباز سدره نشين نشيمن تو نه اين كنج محنت آباد است

تو راز كنكره عرش مىزنند صفير ندانمت كه در اين دامكه جه افتاده است

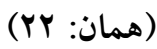

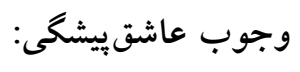

ناخوانده نقش مقصود از كاركاه

عاشق شو ار نه روزى كار جهان سرآيد

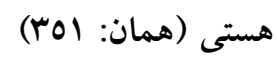

ضرورت ييروى از راهنماى روحانى:

ق قطع اين مرحله بى همرهى خضر مكن ظلمات است بترس از خطر گمراهى

(همان: (هq) (ه)

گرهگثايى (دل) در كشف حقايق و جذب معارف:

سالها دل طلب جام جم از ما مى كرد وانجه خود داشت ز بيكانه تمنا مى كرد كوهرى كز صدف كون و مكان بيرون است طلب از گمشدكان لب دريا مى كرد (همان:

برسشى كه در اين موضع به ذهن مى آيد آن است كه نمونه جنين تمايلات و نيخرانىها

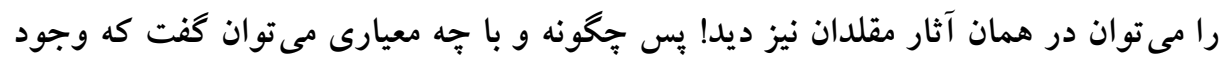

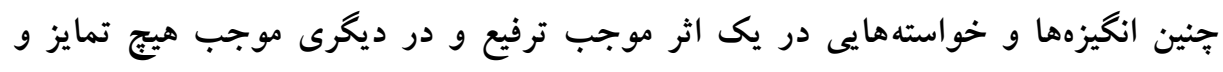

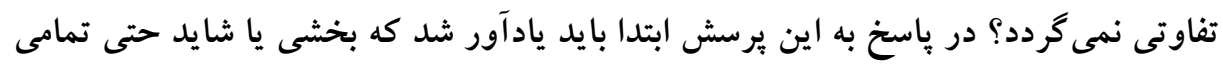

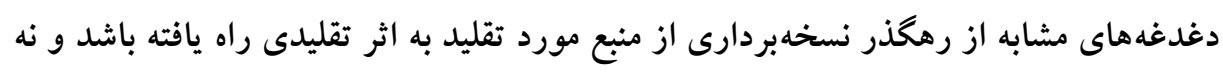
از كاوشهاى فكرى خالق اثر كه بيوسته وسواس و اضطراب انجام (كارى كارستان) دارد: 
قدر وقت ار نشناسد دل و كارى نكند بس خجالت كه از اين حاصل اوقات بريم

(همان: (هY )

بىمأوريتى و بىعملى، لاجرم پشيمانى و خزلان به بار مىآرد؛ اما از كجا بايد شروع

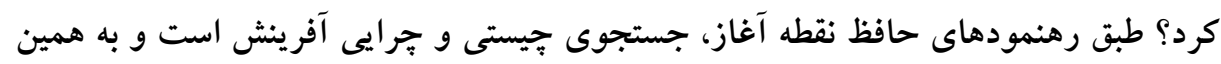

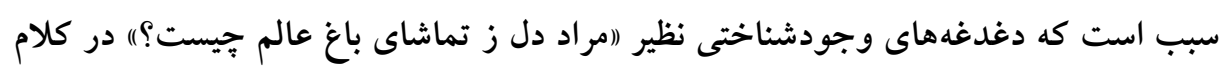

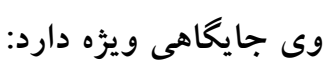

حيف باشد كه ز كار همه غافل باشى در جممن هر ورقى دفتر حالى دگر است

(حافظ: rاr)

علاوه بر اين، دغدغههايى كه در يك شاهكار فكرى-ادبى متبلور مى حضور در متن بلكه با همراهى مولفههاى مكمل است كه به عناصرى ارتقادهنده تبديل مى -

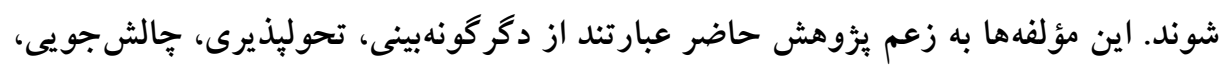

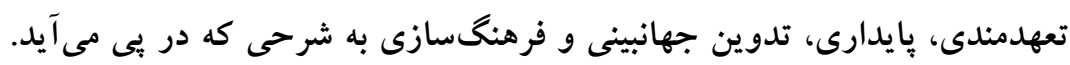
دكر گونهبينى و تحول يذيرى

آشكار است كه در طريق كمال، سير صعودى در بيش گرفتن و در مسير باقى ماندن،

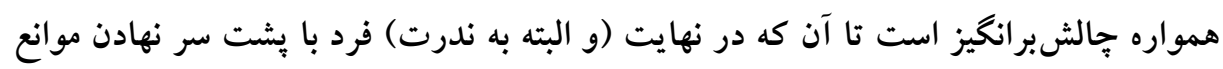

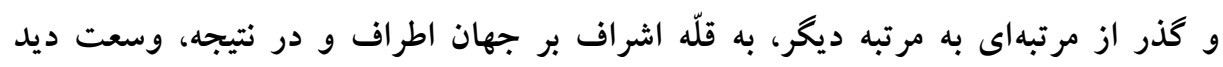

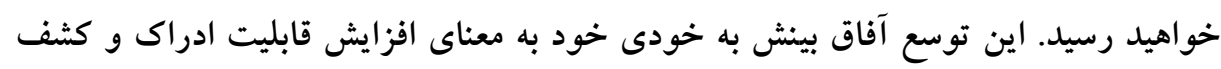

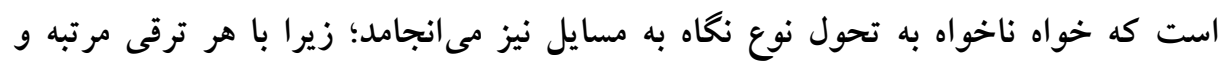

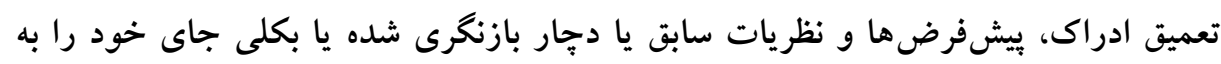

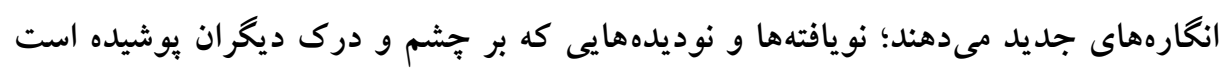

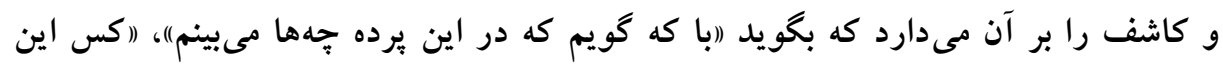

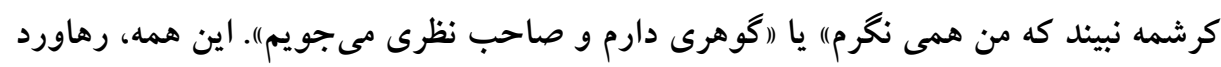

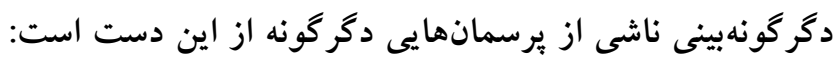


تابيرسد كه جرا رفت و جرا باز آمد عارفى كو كه كند فهم زبان سوسن

(همان: ع IY)

اين ضرورتى است كه اكثريت از آن غافلند و همين غفلت سبب بيحانحى و عدم

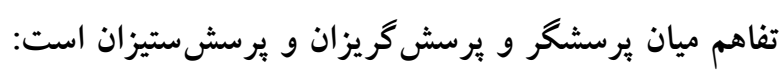
سوخت اين افسردكان خام را دود آه سينه نالان من

كس نمى بينم ز خاص و عام را (همان: ع ()) محرم راز دل شيداى خود يا:

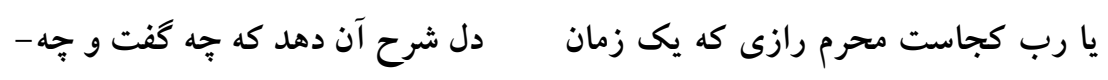

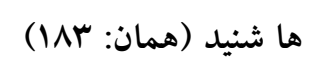
نيز:

$$
\begin{aligned}
& \text { معرفت نيست در اين قوم خدا را سببى تا برم گوهر خود را به خريدار دكر }
\end{aligned}
$$

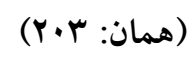

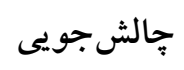

از نخستين بيامدهاى دگر گونى شخصيتى، رويارويى اجتنابنإيذير با مواريث تثبيت شده

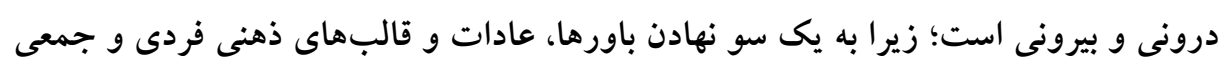

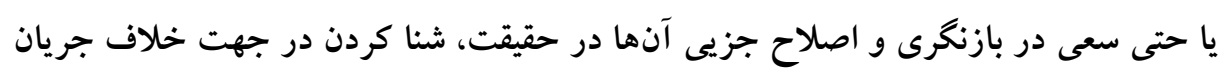
آب آبت است ستع

سير تاريخ زندكانى اكثر شخصيتهاى دورانساز، كوياى اين واقعيت است. اغلب اين

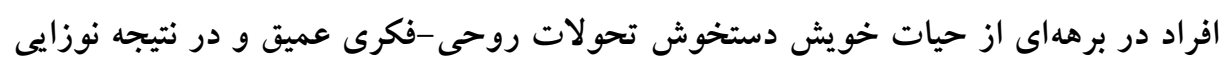

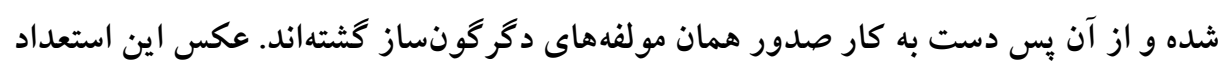

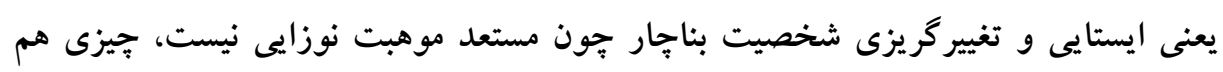

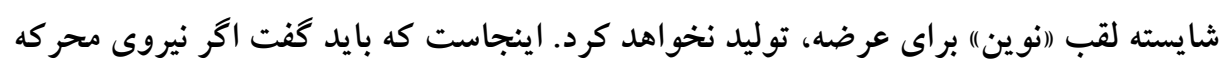


تغيير سبكها تحولات تاريخى-اجتماعى است (شميسا، rیr|: I9V) نيروى محركه توليدات بزرى ادبى، تغيير شخصيت اديبهاست.

از امتيازات بى شمار ادبيات فارسى آن است كه همواره بختى بلند در برخوردارى از

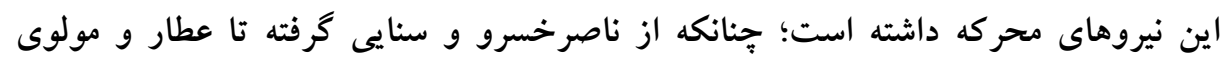

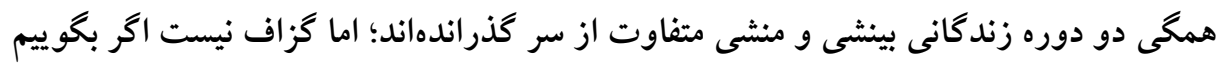
در هيج اثر ادبى كلاسيك فارسى به اندازه ديوان حافظ به طور مشخص با سلسله مراتب

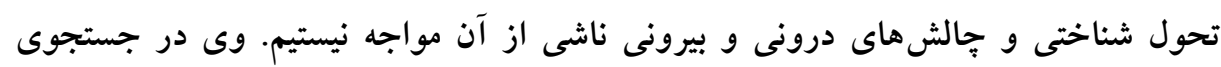

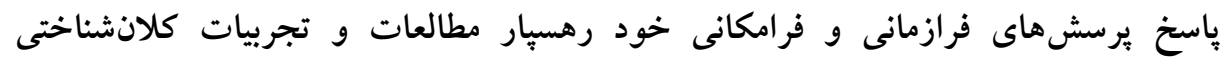

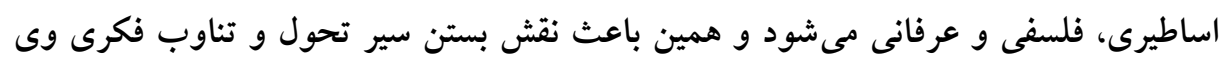
از فلسفى به عرفانى در غزلياتش مى عى درد.

شناخت عرفانى آن نوع از شناخت است كه حافظ را به باسخ همه يرسشهايش در باب

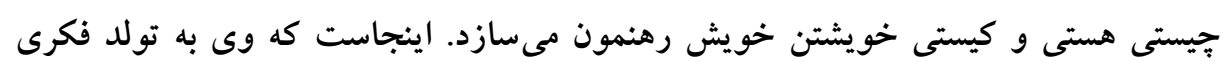

جيست اين سقف بلند ساده بسيارنتش زين معما هيج دانا در جهان آكاه نيست

(حافظ: (ح) )

عيان نشد كه جرا آمدم كجا رفتم دريغ و درد كه غافل ز كار خويشتنم

(همان: (YrV)

ساقيا جام مىام ده كه نغارنده غيب نيست معلوم كه در برده اسرار جه كرد آن كه بر نقش زد اين دايره مينايى كس ندانست كه در گردش برگار

جه كرد (حافظ: r+1)

شاهغزلهايى ماندد (ادر ازل يرتو حسنت ز تجلى دم زد)، (ادوش ديدم كه ملايك در

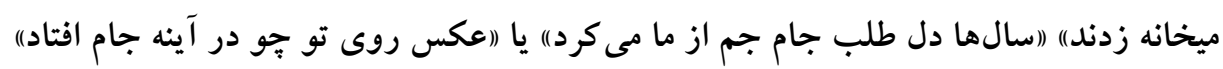

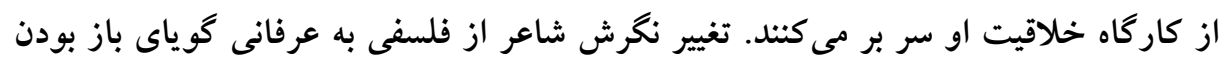


دروازههاى شخصيت وى بر ايدها و انديشهاى نو و متفاوت و در نتيجه، تحول و ترقى معرفتى است.

اين جابه جايى و جايكزينى، طبق انتظار به سهولت رخ نداده است و حافظ نيز ناكزير از

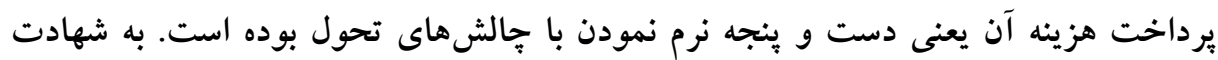

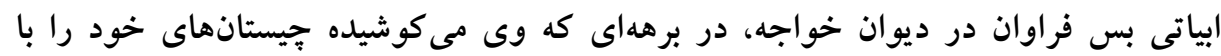

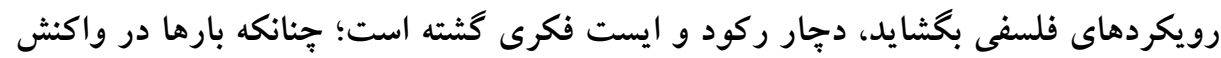

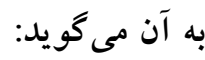

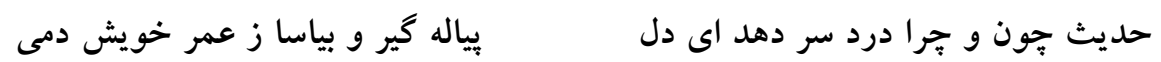

(حافظ: rrr)

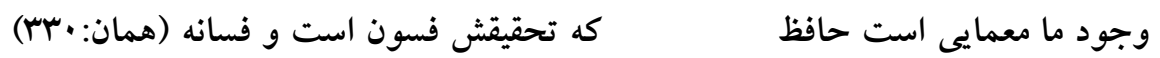
جهان و كار جهان جمله هيج بر هيج است هزار بار من اين نكته كردهام تحقيق ( ( حافظ: (r.7)

بيامدهاى مستقيم اين زمينگيرى و درجازدگى فكرى، بازتاب عوارضى مانند سر گثتخى،

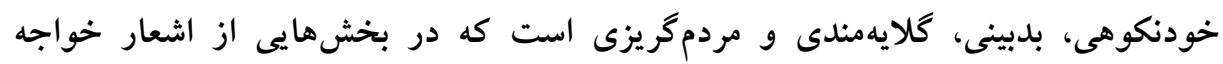

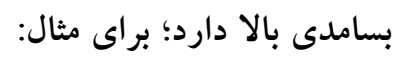

يا رب از مادر گيتى به جه طالع كو كب بخت مرا هيج منجم نشناخت زادم (حافظ: YIN)

كندم قصد دل ريش به آزار دخر هر دم از درد بنالم كه فلك هر ساعت (همان: IV7)

زانكه در كمخردى از همه عالم بيشم شاه شوريدهسران خوان من بىسامان را

(همان: רצr)

اين جه استغناست يا رب وين جه قادر حكمت است 
كاين همه زخم نهان هست و مجال آه نيست

(همان: (YV )

به موازات اين جالشهاى درونى، كشمكشهاى بيرونى حافظ با صوفى شبهه خوار و زاهد رياكار و محتسب تندرو و مردم جاهل و مدعى سستنظم و فارس سفله يرور و شيراز

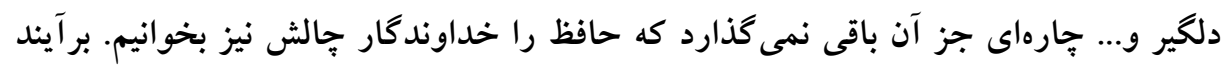

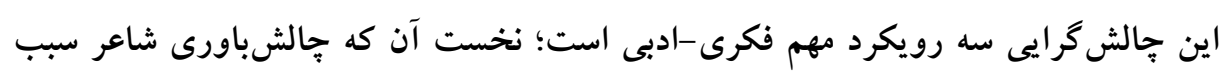

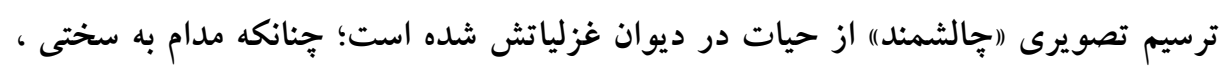

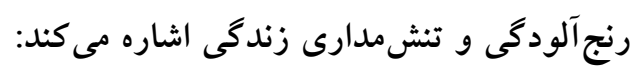

خواهى كه سخت و سست جهان بر تو بحذرد بحذر ز عهد سست و سخن هاى

$$
\text { سخت خويش (همان: Vع) }
$$

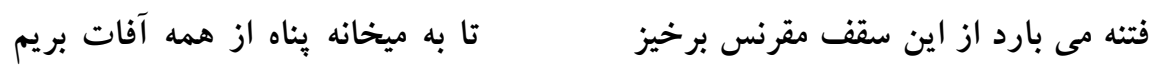

( (همان:

سخت مى گردد جهان بر مردمان كفت آسان گير بر خود كارها كز روى طبع سخت كوش (همان: (Vr)

دوم اين كه به موازات سعدى كه در اخطار به جالشمندى حيات گوشزد مى كند ايها

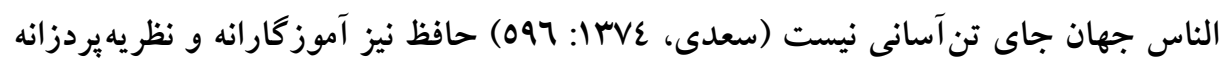

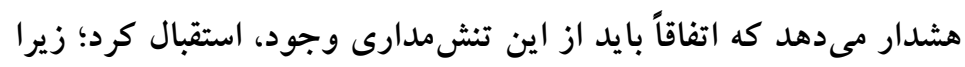
كسب جمعيت از آن زلف بريشان از خلاف آمد عادت بطلب كام كه من كردم (همان: ع זr)

اين در حالى است كه حزين لاهيجى كه يكى از مقلدان تمام عيار حافظ است در ادعايى

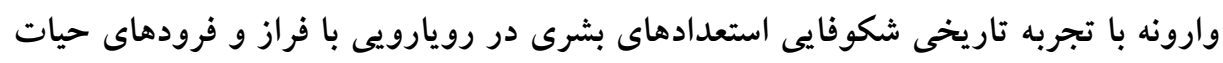

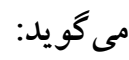

جهان كردمى ير در شاهوار (IrAVY: (EY) نبودى اگر دهر ناساز 
سوم آن كه عوارض فكرى-روحى برتافته از اين جالشها در برتو اين بسامد بالا و

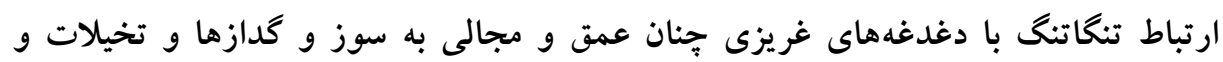

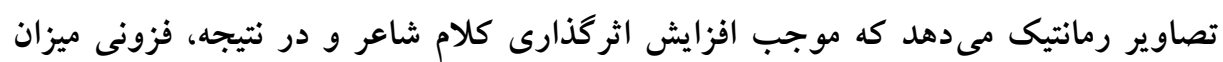

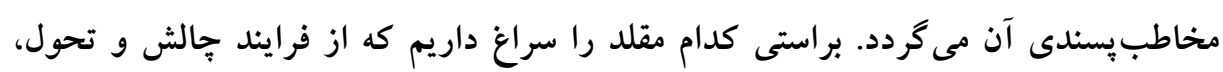

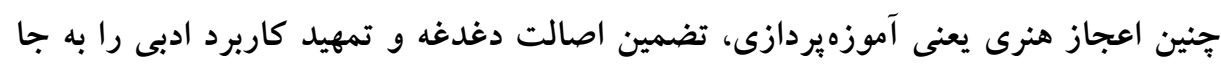

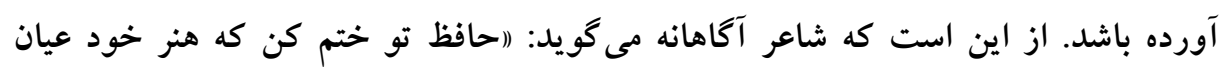

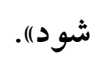

در پايان اين مبحث بايد به عاملى مؤثر در زمينه ارتباط جالشها با توليدات هنرى-ادبى

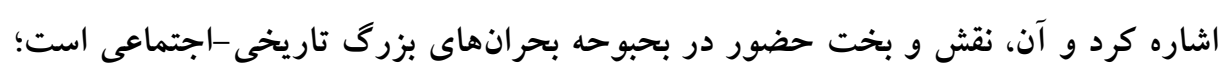

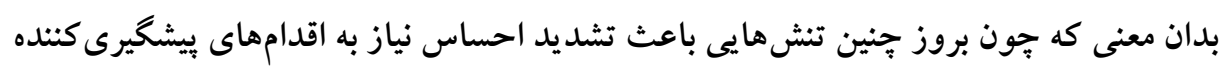

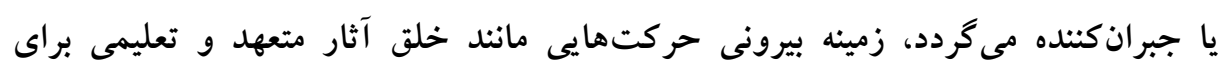

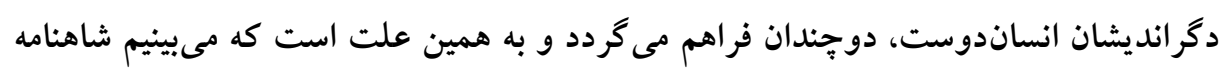

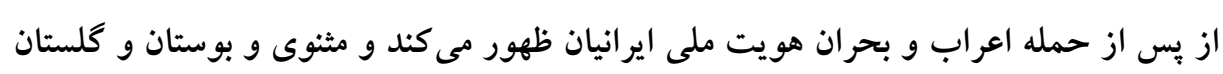

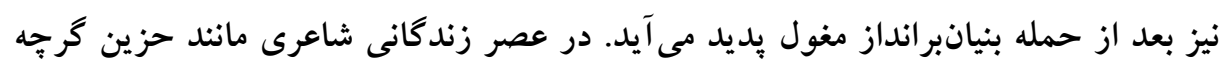

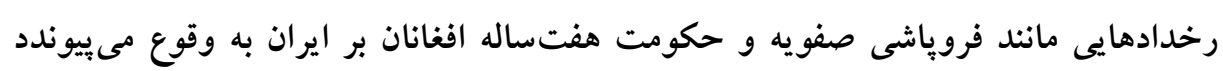

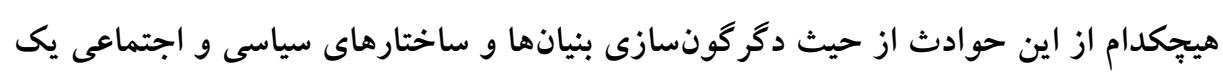

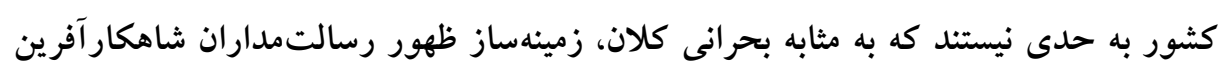

\section{تعهدمندى}

هر گونه ترفيع نخرشى در جهان شخصى فرد بناگزير نويدبخش يرورش دوجندان منش

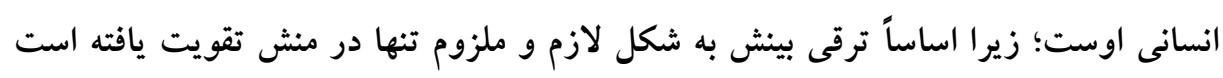

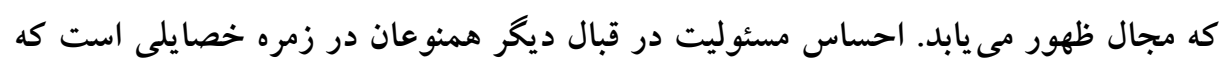
در اين فرايند فزونى مى گيرد و همين امر موجب بروز احساس تعهد بيشاييس در باب دئس انسان 
و اجتماع در فرد متحول مىشود. تبليغ آموزهها و تعاليم برخاسته از همين احساس تعهد سبب

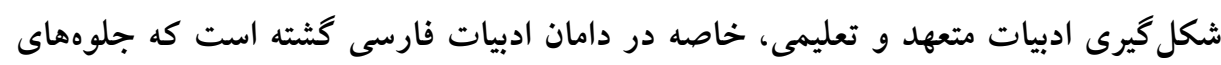

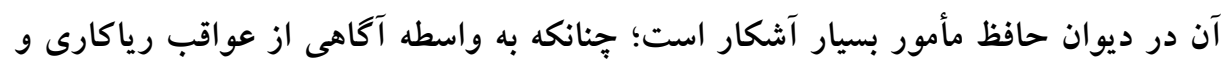

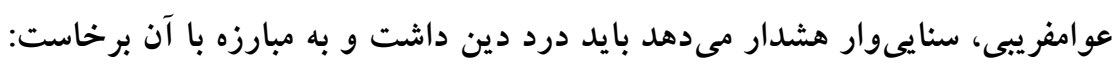
آتش زهد و ريا خرمن دين خواهد سوخت حافظ اين خرقه بشمينه بينداز و برو

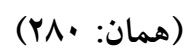

با بذيرش بى باسخى معماى وجود و درك لزوم زيستن در حال، خيامانه در قرون تاريك اشاعه شادزيستى و خوشباشى ميكند:

هر وقت خوش كه دست دهد مغتنم شمار كس را وقوف نيست كه انجام كار جيست (همان: (Y)

با كشف جام جم دل و نجاتبخشى عشق و ضرورت رجعت به اصل خويش، مولوىوار مخاطب را به مشرب كمالبخش عرفان فرا مىخواند: دست از مس وجود جو مردان ره بشوى تا كيمياى عشق بيابى و زر شوى وجه خدا اكرت شود منظر نظر زين يس شكى نماند كه صاحب نظر شوى (همان، با احاطه بر اين حقيقت كه رستخارى جاويد در ترى خودخواهى و بى آزارى و انساندوستى است، سعدى مآب مىسر ايد:

كه در شريعت ما غير از اين گناهى مباش در يى آزار و هر جه خواهى كن

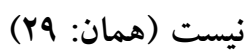

حافظ با ايمان به اين تعهدات و الزامات، به شكلى تلويحى از برخوردارى خويش از

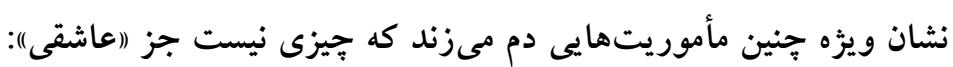
كه در مشايخ شهر اين نشان مرد خدا عاشقى است با خود دار نشان نمى بينم (همان: r09) 
يردازش وسواس گونه و مداوم دغدغهها و جالشها و گنجاندن بىوقفه تعاليم تعهدى در

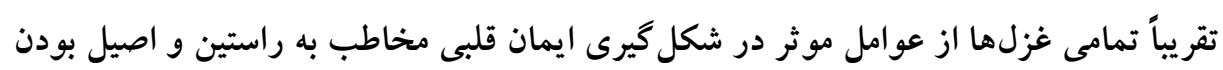

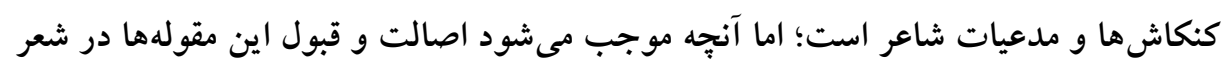

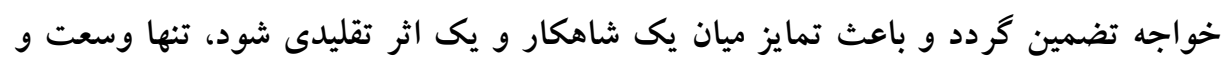

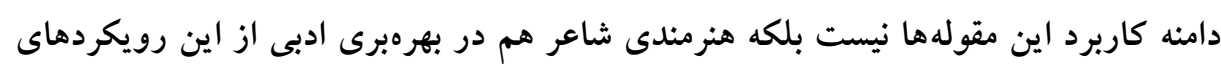

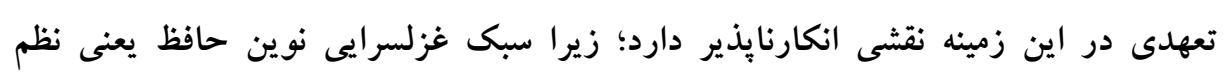

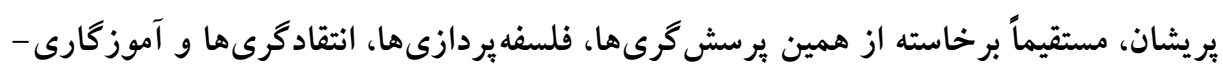

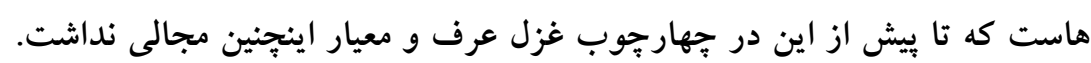

$$
\text { يايدارى }
$$

استقبال از جالشها بدون تجهيز به خصلت مقاومت و مداومت اصولاً حر كتى نامعقول و

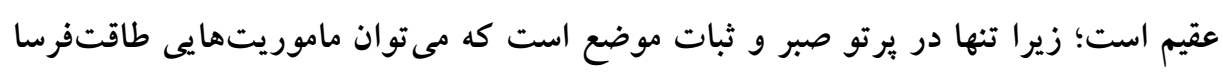

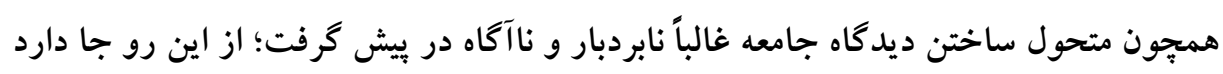

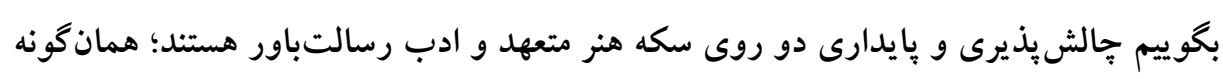

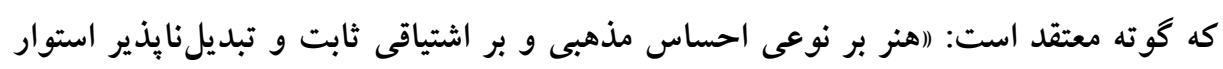

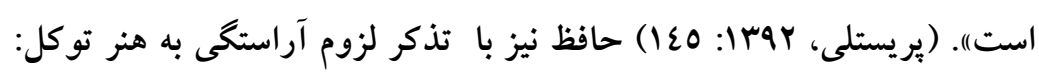
تكيه بر تقوى و دانش در طريقت كافرى است راهرو گر صد هنر دارد، توكل

$$
\text { بايدش (همان: (V) }
$$

در جاى جاى ديوان خود گوشزد مى كند كه رمز توفيق، پايدارى و بردبارى است: با دل خون شده جون نافه خوشش بايد بود هر كه مشهور جهان گثت به مشكين

جان نهاديم بر آتش ز يى خوش تا جو مجمر نفسى دامن جانان گيرم نفسى (همان: (r) (r) 
با دل خونين لب خندان بياور همجِو جام نى گرت زخمى رسد آيى جو جنى اندر

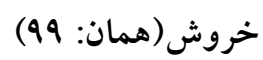

اين كه بيرانه سرم صحبت يوسف بنواخت اجر صبرى است كه در كلبه احزان

كردم (همان: (YY)

اين مشت نمونه از خروار ابيات مبلغ وجوب يايدارى در حصول مراد نيز گوياى آن

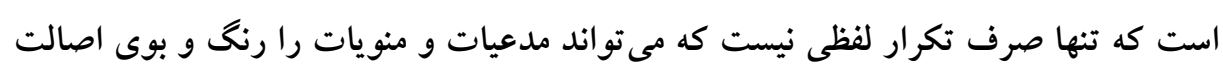

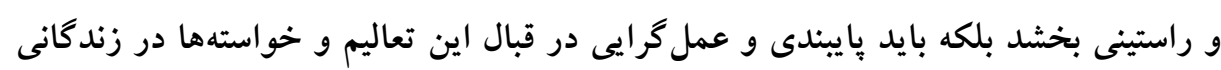
شخصى خود گو ينده نيز نمودى عملى داشته باشد. تدوين جهانبينى و فرهنگسازى

جهانبينى و فرهنگ طبق تعاريف موجود در دايره المعارفها با اندكى تسامح به

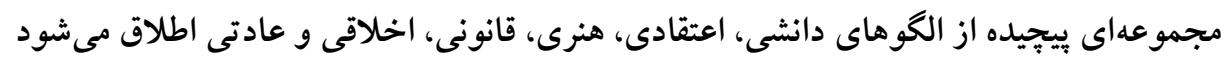

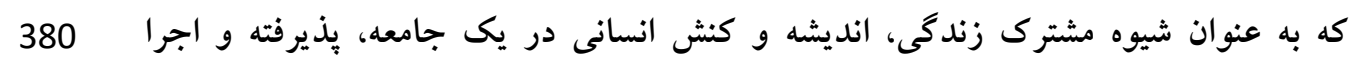

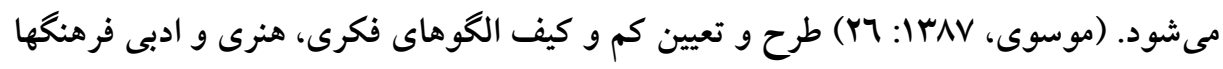

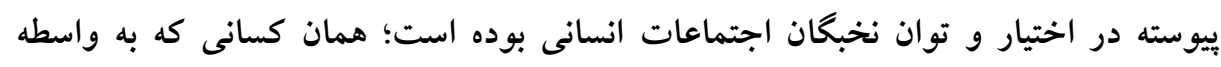

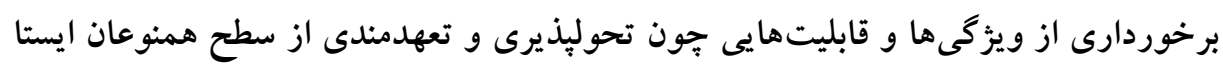

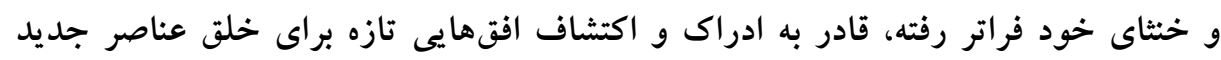

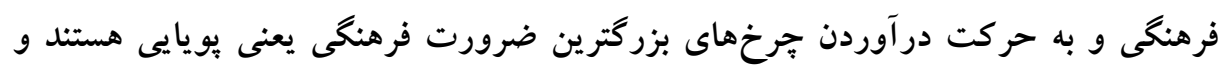
خطر بزر گترين دشمن فرهنگ يعنى ركود را زايل مى سازند.

بر آورد جنين مقصودى در گرو بيى افكندن شالوده يك جهانبينى تازه يا نوسازى جهانبينى

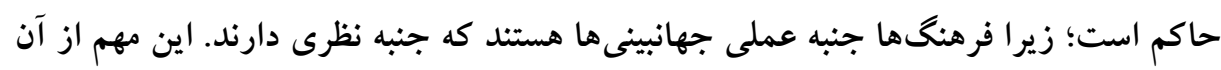

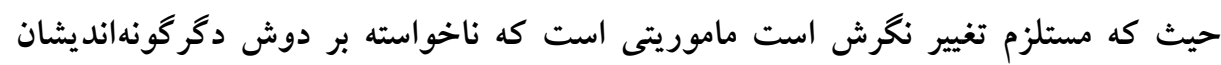

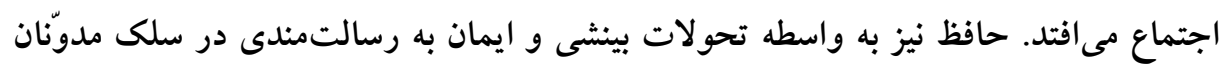

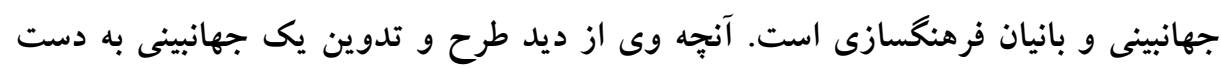


مىدهد عمدتاً همان جهانبينى عرفانى-تعليمى ايرانى-اسلامى است كه بيش از وى در آثار

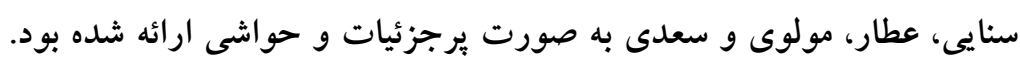

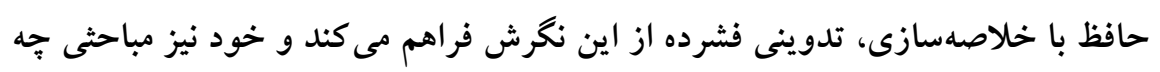

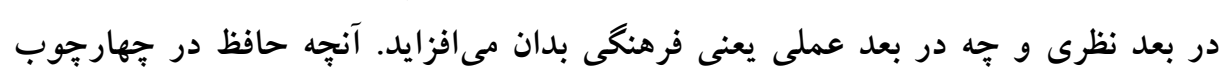

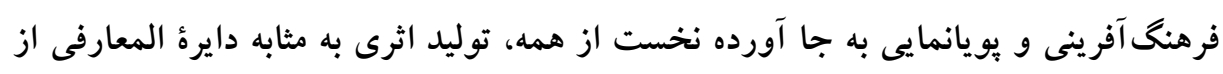

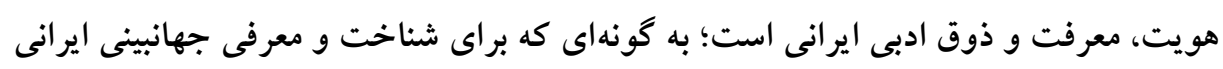
كافى است ديوان حافظ را نامزد كنيم.

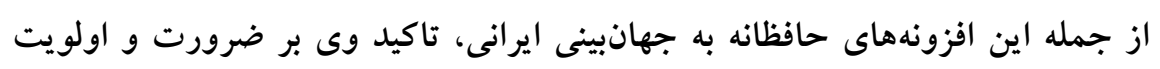

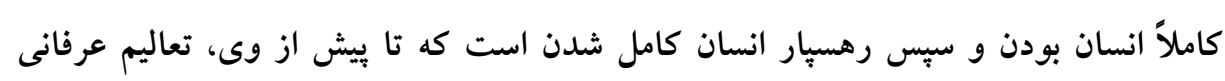

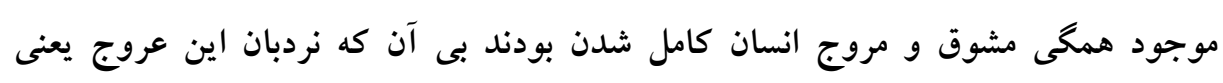

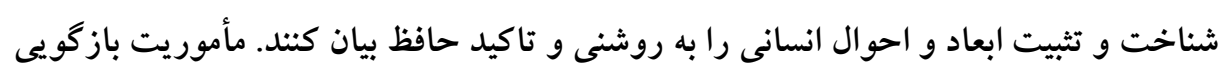

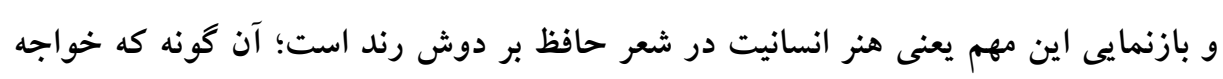
خود آورده است:

رندى آموز و كرم كن كه نه جندان هنر است حيوانى كه ننوشد مى و انسان نشود

(همان: (109) (109)

هم از اين روست كه در كتاب عرفان و رندى در شعر حافظ مى خوانيم: ارندى يعنى

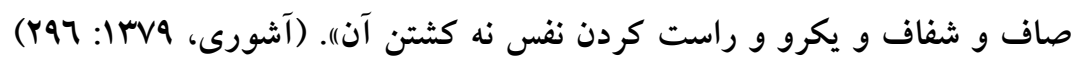

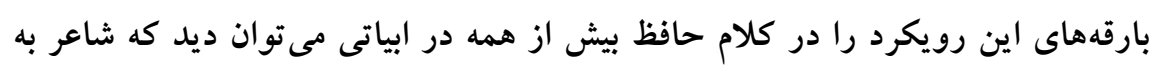

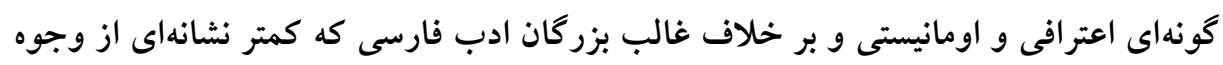

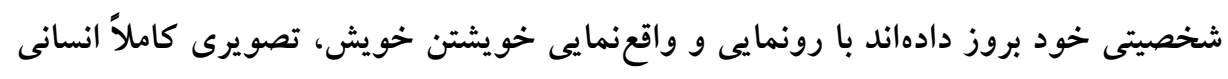

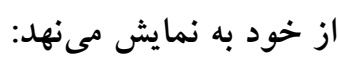

اين متاعم كه همى بينى و كمتر زينم

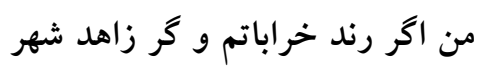

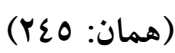


زان كه در كم خردى از همه عالم

شاه شوريدهر ان خوان من بى سامان را

$$
\text { بيشم (همان: بr (Y) }
$$

با به جالش كشيدن مقوله بِيجيده كناه، خواهان و بانى تجديد نظر و قرايتى نو در اين

$$
\text { زمينه مىشود: }
$$

كناه اكرجه نبود اختيار ما حافظ تو در طريق ادب كوش كو كناه من است

(همان: 19) (19)

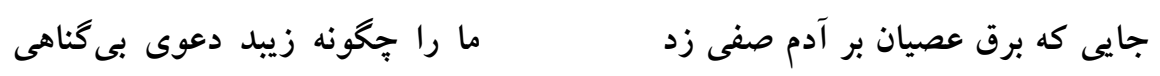

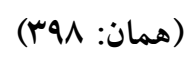

و ياسخكويى و اشتغال به نيازها و لذايذ دنيوى را مقدمه تجرّب و قابليت برخوردارى از

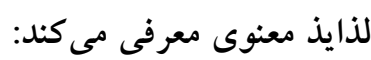

هر آن كه سيب زنخدان ز ميوههاى بهشتى جه ذوق دريابد

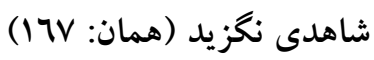

كر از آن آدميانى كه بهشتت هوس است عيش با آدمىاى

$$
\text { جند بريزاده كنى (همان: بrr) }
$$

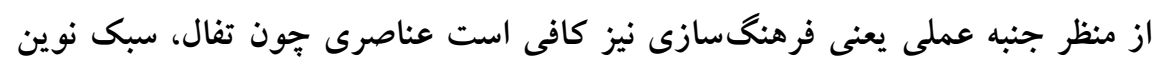

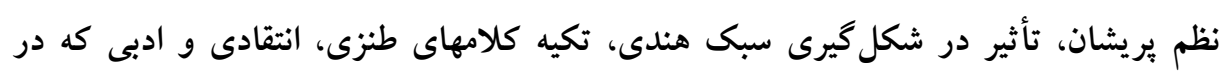

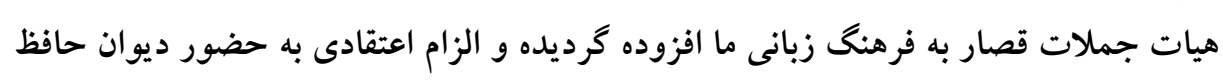

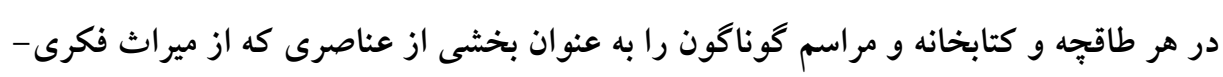

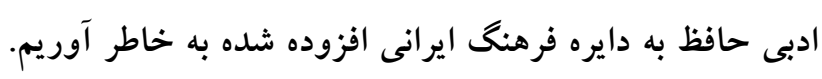

دستبردى شكرف و عظيم همجون دكر كونسازى يا روزآمدسازى يك جهانبينى و

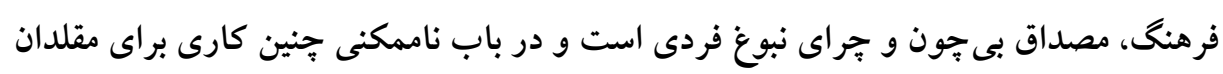

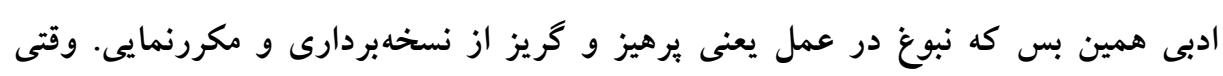

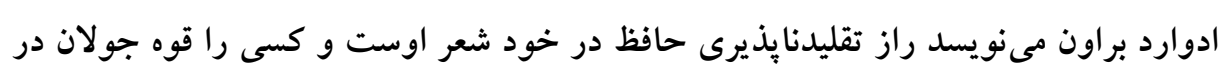


عرصه برواز او نيست (براون، وبها: ra 1) كدام بعد از شعر وى را مى توان در تصديق اين

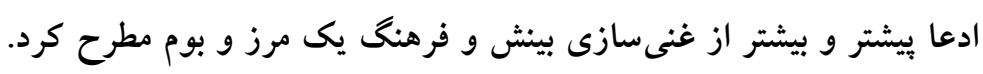
نتيجه كيرى

تعيّن هنرى كه همان تبلور هنرى به معناى عامش است و دو خصيصه مخاطب بِندى و و

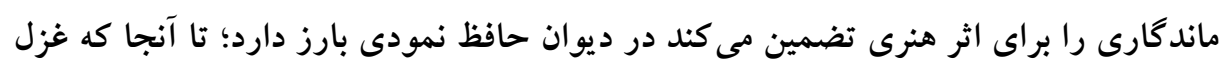

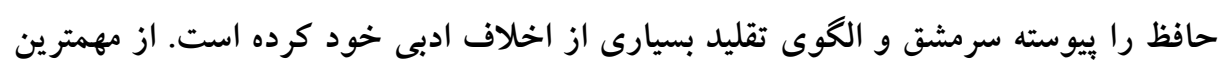

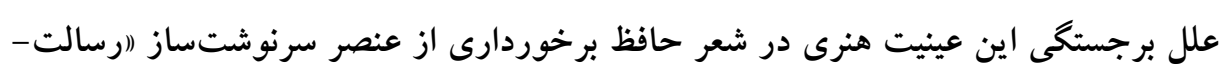

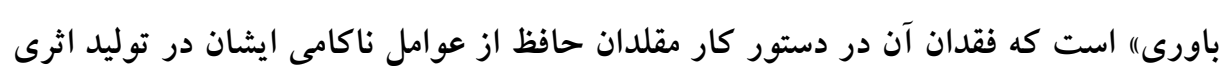

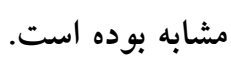

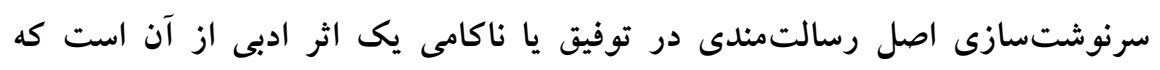

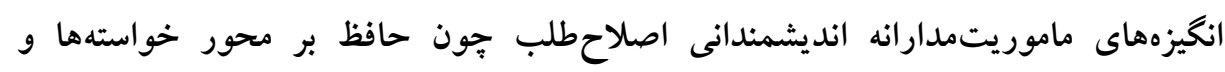

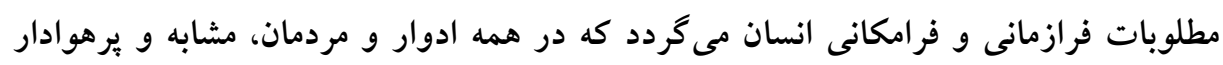

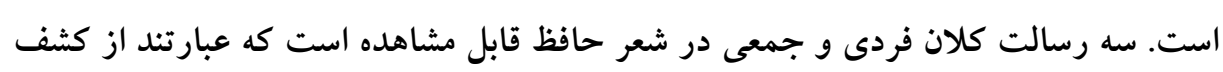

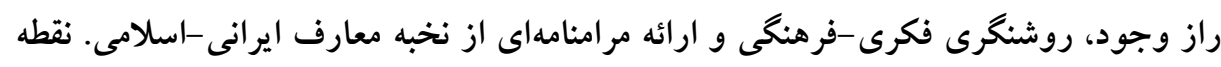

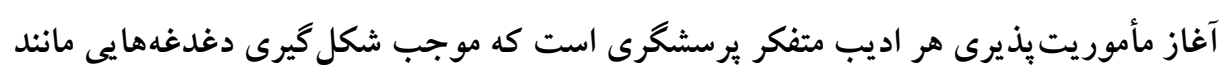

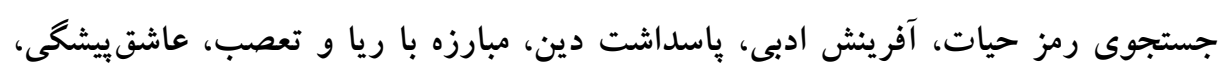

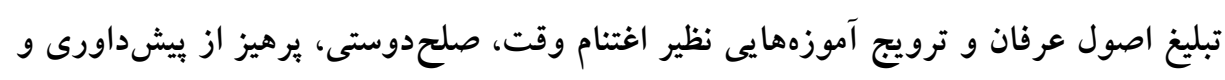
بعى آزارى در كلام حافظ مىشود.

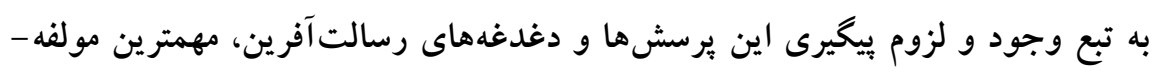

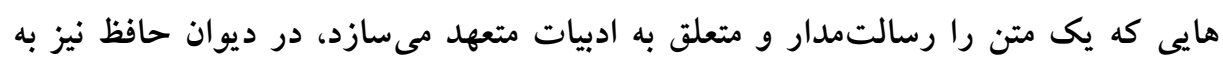

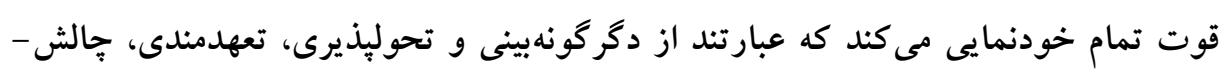

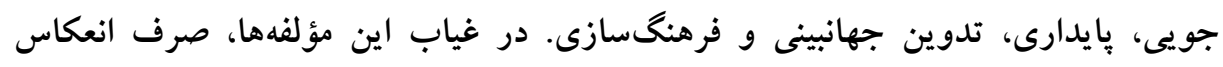

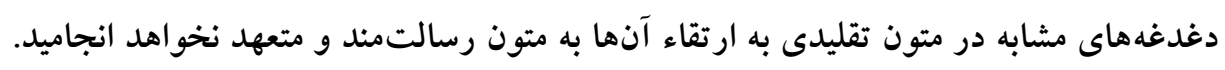




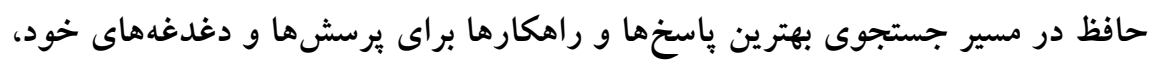

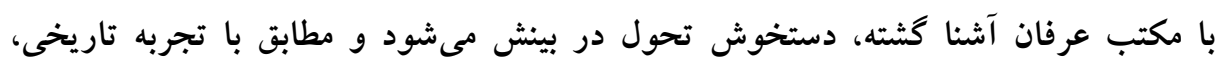

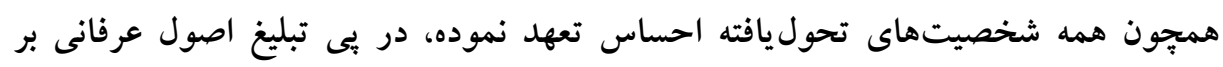

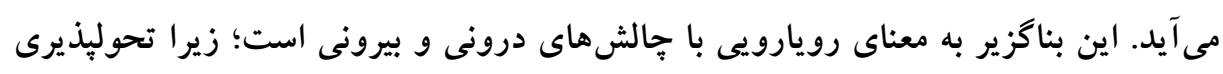

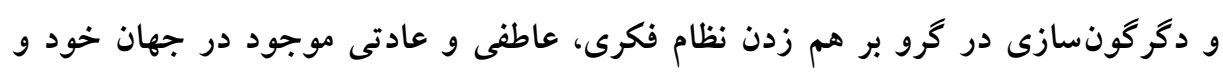

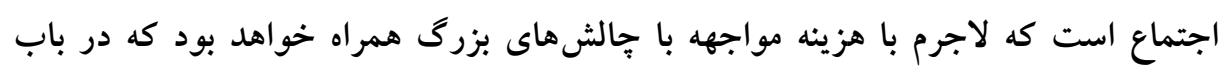

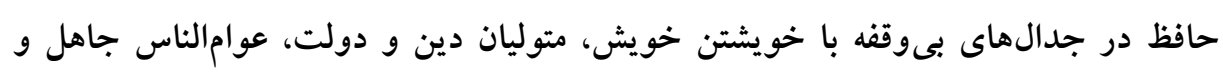

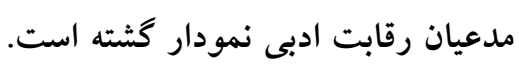

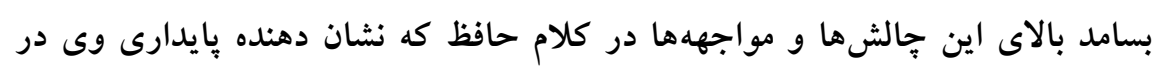

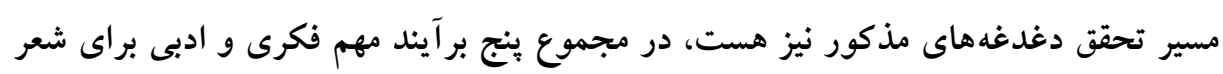

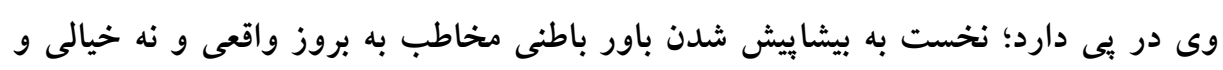

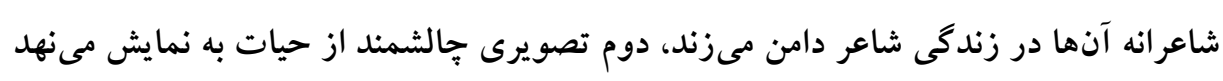

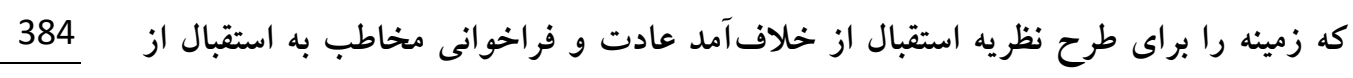

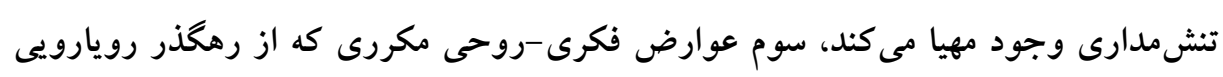

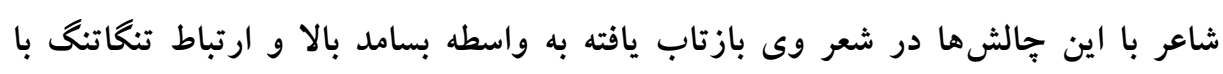

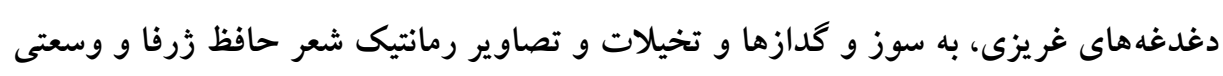

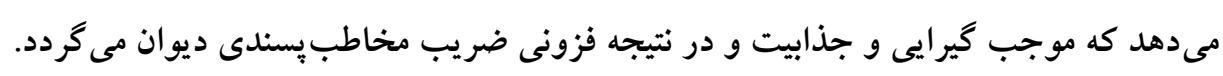

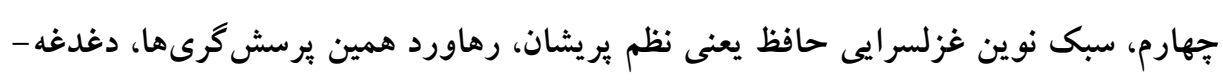

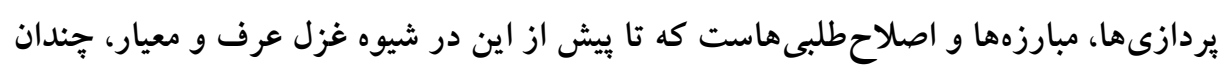

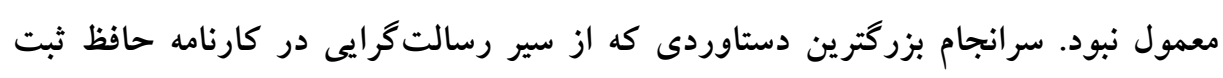

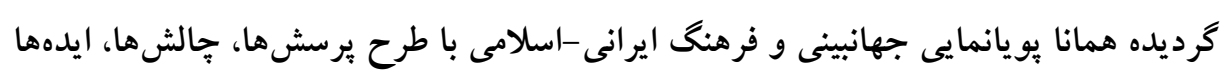

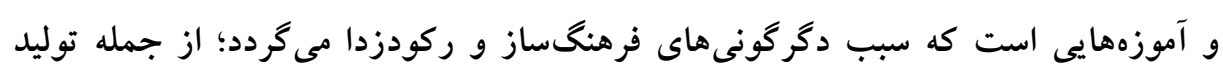

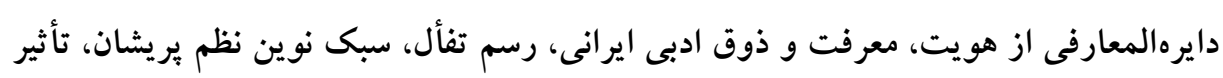

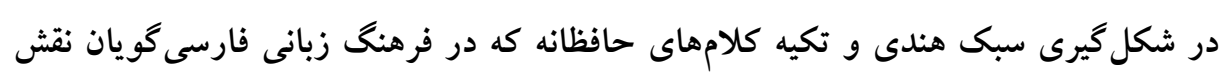




\section{منابع}

آشورى، داريوش (IrVq) عرفان و رندى در شعر حافظ، جاٍ نخست، تهران، نشر مركز. انوشه، حسن (IrVT) فرهنگنامه ادبى فارسى، جلد دوم، جاب نخست، تهران، وزارت فرهنگ و ارشاد اسلامى.

براون، ادوارد (وسrا) تاريخ ادبيات ايران، ترجمه على اصغر حكمت، جلد سوم، تهران، ابنسينا.

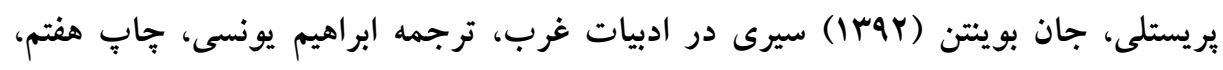
تهران، نشر اميركبير. حافظ شيرازى، خواجه شمسالدين محمد، (IYAVV) ديوان غزليات، به كوشش محمد قزوينى و قاسم غنى، جاب سوم، تهران، نشر روزنه.

حزين لاهيجى، محمدعلى (IrVN)، ديوان اشعار، به تصحيح بيزٔن ترقى، تهران، نشر سايه.

سعدى شيرازى، مصلح الدين. (IrV\&) كليات، تصحيح و توضيح غلامحسين يوسفى، جاب

$$
\text { جهارم، تهران: انتشارات خوارزمى. }
$$

شعار، جعفر (IrOV) (هنر در سخن سعدى)، مجله يغما، شماره rr. شميسا، سيروس، (r/r I سبكثناسى نظم، جاب جهارم، تهران، نشر بيام نور. غنى، قاسم (rara) تاريخ عصر حافظ، جلد نخست، تهران، نشر زوار. فردوسى، ابوالقاسم (YMYY) شاهنامه، به تصحيح جلال خالقى مطلق، تهران، مركز دايره-

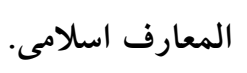

فرزام، جليل (Ira7) هنر، اقتباس، تقليد، جاب اول، تهران، نشر نخار.

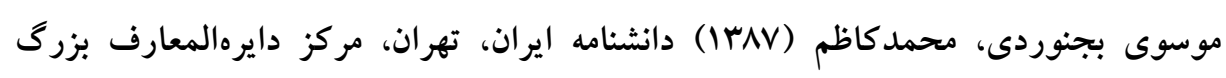
اسلامى. 


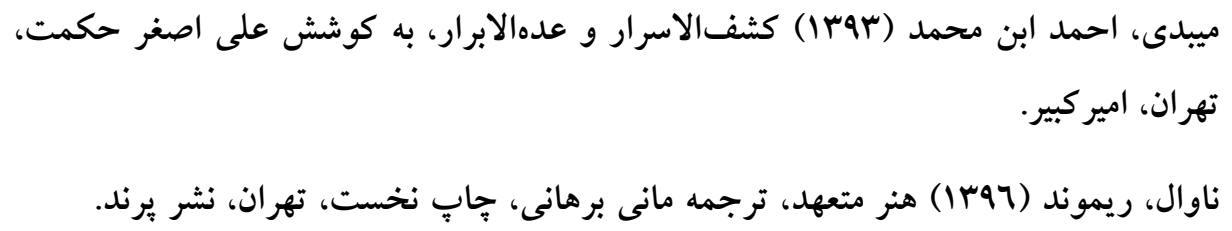

\section{Kaynakça}

Âşûrî, Dâryûş (1379) İrfân ve Rindî der Şiir-i Hâfız, Çap-i nuhust, Tahran, Neşr-i Merkez.

Enûşe, Hasan (1376) Ferheng-nâme-i Edeb,i Fârsî, Cild-i dovvum, Çap-i nuhust, Tahran, Vezâret-i Ferheng ve İrşâd-i İslâmî.

Browne, Edward (1339) Târîh-i Edebiyât-i Îrân, Ter: Ali-Asker Hikmet, Cild-i Sevvum, Tahran, İbn-i Sinâ

Priestley, John Boynton (1392) Seyr-i der Edebiyât-i Garb, Ter: İbrahim Yûnisî, Çap-i Heftum, Tahran, İNeşr-i Emîr Kebîr.

Hâfız-1 Şirâzî, Hâce Şemseddin Muhammed (1387) Dîvân-1 Gazeliyyât, Be kûşiş-i Muhammed Kazvînî ve Kāsım Ganî, Çap- Sevvum, Tahran, Neşr-i Ruzene.

Hazîn-i Lâhîcî, Muhammed Alî (1378). Dîvân-i eş'ar, Haz: Bîjen-i Terakkî, Tahran: Neşr-i Sâye.

Sâdî-i Şirâzî, Muslihiddin (1374) Külliyât, Haz: Gulâm- Hüseynî Yûsufî, Çap-i Çaharum, Tahran, İntişârât-i Hârezmî.

Şu‘âr, Ca‘fer (1357) Hüner der Suhen-i Sâdî, Mecelle-i Yeğma, Şumara-i 32

Şemisa, Sîrüs (1375) Sebk-Şinasi-yi Nezm, Çap-i Çaharum, Tahran, Neşr-i Peyâmı Nur.

Ganî, Kâsım (1393) Târîh-i Àsr-i Hâfız, Cild- Nuhust, Tahran, Neşr-i Zevvâr.

Firdevsî, Ebü'l-Kāsım (1382) Şahnâme, Haz: Celâl Hâlikî Mutlak,Tahran, Merkez-i Dâiretü'l-Maârif-i İslâm

Ferzâm, Celil (1396) Hüner, İktibas, Taklit, Çap-i Evvel, Tahran, Neşr-i Nigâr.

Mûsevî Bocnûrdî, Muhammed Kazım (1387) Dânişnâme-i İran, Tahran, Merkez-i Dâiretü'l-Maârif-i Buzurg-i İslâm.

Meybûdî, Ahmed ibn Muhammed (1393) Keşfü'l-esrâr ve 'uddetü'l-ebrâr, Be kûşiş-i Ali-Asker Hikmet, Tahran, Emir Kebir

Naval, Reymond (1396) Hüner-i Müte'ahhid, Ter: Mani Burhani, Çap Nuhust, Tahran, Neşr-i Perend. 